\title{
The Homeric poems in Romanian attire. A diachronic analysis (II)
}

\author{
Petre Gheorghe Bârlea* \\ Faculty of Letters, “Ovidius” University, Aleea Universității 1, 900472 Constanța, Romania
}

\section{Article info}

History:

Received October 6, 2015

Accepted October 25, 2015

Published February 12, 2016

Key words:

translation

literary language

diachrony

phonetics and morphology

lexical-semantic renderings

localization

\begin{abstract}
In this article we continue the diachronic analysis of the Romanian versions of the Homeric poems, cf. Bârlea (2015c). The triple perspective of the approach is being maintained: a) the evolution of international Homeric studies, which facilitates evermore detailed and exact editions of the Homeric texts; b) the evolution of the literary Romanian language in the period considered (1837-2012), with some references to older periods; c) the differences between translational choices. This time we are concerned with more distinct domains in the language structure of the translations-phonological-morphological and lexicalsemantic aspects. Special attention is paid to linguistic localizations, closely linked to the mentalities and historical realities of the Romanian space of circulation of these successive translations from Homer. In the first case, we have concentrated on the problems of orthography and stress, while in the second we have considered not only the diachronic distributions of word forms and meanings, but also their diastratic and diatopic location.
\end{abstract}

\section{Spelling and phonetism}

1.1. From the notation of the names referring to characters, places and objects to the combinations of everyday words, the particularities regarding the spelling, the stress and, in general, the phonetic and morphological renderings in Romanian contributed visibly to the success or failure of the corpus of translations from Homer offered to modern culture. Not only the older versions, written in Cyrillic or transitional scripts, but also the subsequent ones resorted to forms such as Ermia for Hermes, Efest for Hefaistos, Evripil for Eurypylus or Thetis - transcription valid both for the name of Achilles's mother, the Nereid Thetis and for Tethys, the wife of Oceanos. Ignoring the rough breathing and the correct stress in Greek orthography, in forms such as Iperion for $\Upsilon_{\pi \varepsilon \rho i \omega \nu}$ and using the fricatives $c e$, $c i$, inexistent in Greek, for names such as Forkys, Okeanós, also became customary in Romanian translations. Certain subtleties could not even be fully observed in the versified Romanian forms: Abile / Ahiléu, Odysséu / Odýsseu had shifting stresses even in the original text.

1.2. Even more conspicuous are the stress changes in Romanian, this time exclusively due to metrical constrictions. When a form such as intr-ärmă was criticised at GM, the objection concerned the bold morphological-lexical modification, but of course the term also shocked by the change of stress. However, the usual form inarmează [arms himself] could by no means have been fitted into the verse. Such segmental and supra-segmental licences occur everywhere in Romanian, including the balanced version of CP or the savant one of DS. The former case evinces the frequency of the adverb apoi [then], used at the beginning of each verse as a multifunctional linker. However, this position shows that it must be read as ápoi, because it can only have a trochaic structure. By extension, the stress form thus adapted can also be found inside the verses, which was no longer acceptable at all. In the version DS, the change of stress, operated concomitantly with the morphological-lexical one, also helps ensure the natural flow of

*Email address:gbarlea@yahoo.fr. 
the verse: cu-aleasă făgádă [with solemn oath] (DS-I, XXI, 99); Troienii cei trüfași [the proud Trojans] (DS-I, XXI, 55). Sometimes, in context, a usual word completely loses its natural stress, which is taken over by the previous monosyllabic word, intended to be the first subunit of the respective metrical foot: dară nù-l putu sparge [but he could not break it](DS-I, XXI, 164).

1.3. In numerous other cases, the changes of the phonetic structure are not explicable by ratione metrica, but by the source used, the conventions of the age in the history of Romanian language and culture, and, not least, by the strictly personal choices of the translators: G. Coșbuc writes Atene, not Atena or Athena, simply because this was how the German "original" he had used as a source-text had transliterated the Greek $A \vartheta \eta \dot{\eta} \eta$. When modern translators began to render the pronunciation reconstituted from the original, such as Chaos, the gesture was frowned upon as an attempt to return to the etymological approach, by relation to the phonological script system of Romanian. The critiques against some aberrant stress forms were justified (îmi dèteși [gave me], raspấnde [spreads], guvèrnă [governs], se-n-creàstă and many similar others - at GM), although modifications of stress, especially in conjunct forms, occur even in the neatest Romanian versions, cf. pe care-i ucis-am [whom slay I did], at DS. Otherwise, some "barbarisms" have been unanimously accepted, especially in onomastics, and are to be found in the editions up to 2012, considering that they have become definitively fixed in Romanian common use - Egist [Ægisthus], Elena [Helen], Fedra [Phædra] (DS-I, p. 401).

1.4. We add here-only in passing, for now - the problem of the euphonic effects in the battle scenes and other passages. They have to be discussed at length in a chapter devoted to pragmatic-stylistic elements. Actually, such suggestions are more difficult to detect in the original, and the clearly visible ones are palely rendered in the first Romanian versions (as well as in those in other languages, for that matter), since the equivalents means seemed to be lacking. As the academic text editions included in their critical apparatus more and more observations from the specialists regarding this kind of stylistic refinement, the literary variants of the target languages also evolved. In Romanian, the images based on an imitative sonority became veritable feats of virtuosity beginning with G. Coşbuc ${ }^{1}$ and G. Murnu, Homer's translators of the new century. To the example rendering Il., XVII, 50 and 56-57, we could add a few other scores, well phrased in Romanian, up to Dan Sluşanschi.

Se prăbuși, greu bufnind - zuruiră pe el grele zale,

Vînturi vuind de prin zäri...

Dară, bătînd viforos, vine vîntul cu vaier, furtună.

[He fell, heavily crashing - clattered his weighty armour,

............................

Winds howling from afar...

But, blowing stormily, comes the wind with wailing gale.]

(DS-I, XVII, 50; 56-57)

Usually, if the synesthetic phrase cannot be found, Homer's multiple sensorial imagery-visual, auditory, dynamic - is rendered by successive notations, well integrated, however, in the verse structure:

...iar pe trupu-i arama sclipindă

Greu zurui și cumplit, cum, ferindu-se el intr-o parte,

Tot alerga, cînd acela-l urma cu vuinde vîrtejuri.

[...and on his body the glittering copper

Heavily clattered terribly, as, feinting sideways

\footnotetext{
${ }^{1}$ We should remember that G. Coşbuc was the poet who provided the classical example of alliteration in the treatises and handbooks of stylistics of the Romanian language (Prin vulturi, vintul viu vuia... [Through wings of vultures the wind wildly whirled...]).
} 
He ran as that one followed with whirring whirls]

(DS-I, XXI, 254-256)

1.5. The innovative spirit in the Romanian language was also manifest in the spelling of the morphological and syntactic structures, very clearly delimitated lexically in contemporary Romanian. They can be found more frequently in the beginning, due to the lack of orthographic norms and to the difficulties in typographic printing (cecauți aci; să vezi amea necinste, ce'mia făcut Atrid; fatal'alui trufie and so on, CA-I, I, 221-224 / p. 10). Some inevitable ones also appear at CP or DS (deolaltă, deodat'). Such innovations became annoyingly abundant at GM, as they were part of the rectifying creative zeal manifest on all fronts, characteristic of the Homer scholar en titre of more than half a century in the history of Romanian literary language. Not only the merciless critic V. Eftimiu, but also the brethren of George Murnu drew his attention to some forms that were totally unacceptable according to the academic norms, but also according to the norms of everyday speech, already unanimously accepted by the time Murnu launched his innovations: dupolaltă, întreolaltă, pesteolaltă, lîngăolaltă, laoparte; învremece, dasta, măcarcă, pînăce, de treiori, etc. (cf. Herescu, 2011, p. 373-375, 381)2.

\section{Lexis and semantics}

2.1. Naturally, the form and signification of the words in the Romanian translations constituted the level the most visible and the most frequently subjected to the evaluations in the history of the modern reception of the Homeric texts. The conclusion of our analysis, regarding both the texts proper and those related to their reception and evaluation in the course of time, evinces a spiralling pattern in the evolution of successful renderings in this sense. From the effort to observe the original term or phrase, in a Romanian language still not settled in the framework of literary practice (C. Aristia, I. Caragiani), to the philological scruples combined with the poetic flair of recent times (Hâncu-Diamandescu, but especially D. Slușanschi), the vibrations of the upward spiral were provoked by the poetic daring of G. Coşbuc and especially G. Murnu, or tempered by the minimalism of E. Lovinescu and the balance of C. Papacostea.

The lexical selection, not at all easy in a text of such nature, evolved along a few dominant directions.

2.2. Lexical invention was self-implied, considering the differences of culture, civilization and mentality, accentuated by the temporal distance between the users of the two languages.

a) From the very beginning, Romanian translators needed to resolve the problem of blended compounds (adjective + noun, etc.) in the "permanent" Homeric epithets. Some renditions proved to be inspired and endured in time, from C. Aristia to G. Coșbuc and G. Murnu, for instance brațalba [arm-white] for $(\vartheta \varepsilon \dot{\alpha}) \lambda \varepsilon v x \omega \dot{\lambda} \varepsilon \nu \circ \varsigma$, that is for Hera, the wife of Zeus. It is true that, otherwise, the epithet could hardly be fitted even into the Romanian catalectic dactylic hexameter, and practically impossible within the iambic hendecasyllable of the rhythmical octaves (typical of Ariosto) in GC or within the white hendecasyllable in the version of GM. The natural renditions in Romanian were only possible in prose - (cea) cu brațe albe [the white-armed]. Likewise, the more recent generations took over from the $19^{\text {th }}$ century translators such formulations as regii păstori de popoare [kings shepherding peoples], pedestraşii stavilă-n bătaie [pedestrians shielding in battle], with natural personal variations, cf. GM - stavilă [weir]; zid la război [barricade]; $\mathrm{HD}$ - zăgazprimejdiei [damming danger]. Other such morphological-lexical calques did not last (argintarcatul [the silver-bowed], de nalt tunătorul [the sky thunderer], incofraţii [the brethren]). In fact, C. Aristia himself alternates the compounds with an appositional function when the context requires: for instance, ped-agerul [foot-quick], but also de picior iute [swift-footed] for Achilles. The latter formulation was definitively assimilated, not without nuances—cel iute de picior [the swift-footed one], at GM and all those in his wake-and not without failed attempts at alternation, such as şoimanul [hawkish] Abile, at the same GM. But there will be further occasions to talk about permanent and ornate epithets...

\footnotetext{
${ }^{2}$ It should be noted that, before becoming the official defender and eulogist of GM, Herescu had criticized these forms in a review which he seems to have forgotten (Herescu, 1929, p. 68-70).
} 
b) Many other types of words and phrases caused arduous searches into the lexical stock of the target language, or, when necessary, challenged the translator's personal creativity. I. H. Rădulescu believed that in everyday lexical use it was relatively easy to call mersului - mers [walk], sabiei - sabie [sword], brațului - brat $[\mathrm{arm}]$, and that it was only the names and epithets for the deities that posed problems in such a translation (I. H. Rădulescu, Editorul [The Editor], in CA-I, p. VIII). In reality, in order to render Homer "in his essence", even the most banal words must be chosen with care. Sabia [the sword] in the above example is part of a certain terminological area, and, besides, the generic word does not always cover the respective type of weapon, for they were not similar in conception and aspect in the military equipment of the two peoples. More plainly, any word lends itself to special selections of a synonymic series. There are thousands of examples in the texts discussed here. For the time being we shall refer to the most notorious one.

Today it seems that the first verse of the Iliad could not have sounded, in Romanian, otherwise than we all know it:

Cîntă, zeiță, mînia ce-aprinsepe-Abil Peleianul (GMD-I, I, 1)

[Sing, goddess, the wrath of Achilles Peleus' son]

The formulation belongs to G. Murnu and it was taken over, as a token of homage, by D. Slușanschi, since it had become somewhat "sacramental" (DS-I, p. 510), be it only due to the wide circulation of the GM versions. It was not easily achieved, though. In the first notorious translation in the Romanian linguistic space, that of 1837 , belonging to Aristia, the verse-very faithful to the original-sounded thus:

Mînia cîntă-mi, Zee, a lui Pilad Ahil (CA-I, I, 1)

[Of wrath sing, She-god, that of Peleus' Achilles]

Aristia explains at length, in the corresponding note, the choice of the vocative Zee: zinna [fairy] it could not be, as $\Theta \varepsilon \dot{\alpha}$ means much more in the Olympus' hierarchy, namely "zeiță” [goddess]; but to him zeiță sounded like Zoița [Little Zoe] in the Romanian of the age; Zeă was "irregular" and phonetically "ugly", Zeo sounded like Stano; therefore he was only left with Zee, by which he wanted to "rumănească" [Romanian-ize] the term, since "Deus, dea gives zeu, zee", thus clearly corresponding to the feminine form of Zeu [God] (CA-I, p. 31).

Then, we have to remember that neither did G. Murnu suddenly have the providential inspiration that helped him carve in Romanian marble the famous Greek verse. In the famous edition of 1920, which fructified the efforts of two decades and, for the first time, fully enshrined the ancestor of universal poetry in our national culture - for it was an integral translation, elegantly printed and illustrated, rewarded with the Great Award of the Romanian Academy-the invocation reconsidered the very vocative avoided by his predecessor of the 1848 generation, though in an ill- chosen popular variant:

Cîntă, zeițo... (GM-I, I, 1)

[Sing, goddess...]

Could it be that Murnu had not read Aristia's text? Even if the latter had been criticized by many professional readers, culminating with $\mathrm{N}$. Iorga, his explanations are full of common sense, and his version of 1837 remains foundational. Murnu's initial choice (1920) was promptly and unsparingly objected to as a proof of the lexical depreciation of the Homeric text, exactly in the well-known terms: "Zeițo sounds like

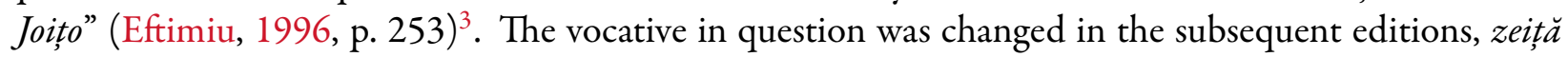
[goddess] remaining emblematic for the Romanian wording of the incipit of the Iliad. In the course of

\footnotetext{
${ }^{3}$ The reputable poet, dramatist and journalist Victor Eftimiu does not hesitate to describe this form as, quite justly, as "a vulgarly familiar vocative". Once unleashed, the diatribe goes on by extracting some similar examples: ochioaso, deliu, mai dihai, abraşd and others are samples of "dubiously coloured slum vulgarities" (Eftimiu, 1996, p. 253).
} 
time, however, there were also other conjectures, proposed by all those who tried their hand at translating the Homeric verse. The test of time, namely the evolution of the literary Romanian language definitively validated the Latin type variant "vocative = nominative".

But this is only one of the five words in the first verse of the Iliad, which became eight in Romanian,

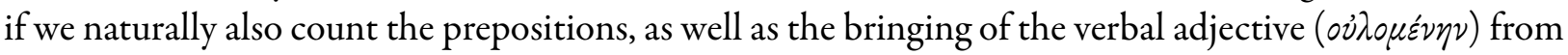
the second verse of the original:

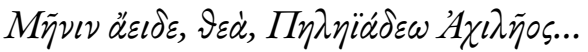

The search for a correspondent of the epithet describing Achilles also involved an arduous search, as part of the permanent problem of the formulaic canon already much discussed in these pages. We will mention here only two of the proposed solutions. Thus, of the relatively recent ones, the prose version HD observes the pattern of the Homeric sentence, avoiding the dislocation caused by Murnu. The result is a correct sentence, faithful to the syntactic unit in Homer, though lacking the brilliance of the verse consecrated in Romanian:

Cîntă, zeiță, mînia Peleidului Abile (HD-I, I, 1)

[Sing, goddess, the wrath of Peleus' Achilles]

In a translation shortly preceding that of D. Slușanschi, the classicist Nicolae Georgescu offers another reorganization of the sentence proposed by his magister, with the attendant change in the patronymic epithet:

Cîntă zeiță, de-Abile Pelidul cu furia-i oarbă... (cf. Georgescu, 2005, p. 31)

[Sing goddess, of Achilles of Peleus and his blind fury...]

He thus obtains a harmoniously cadenced verse, well integrated in the metrics and prosody of both the original and of the target language, though at the cost of increasing the number of the lexical units from five to nine. In fact, what matters is not the quantitative aspect, by saving the original unity between the logical-syntactic statement and the sound rhythm pattern.

But NG's rendering sends us to another word in the same line, which generated arduous searches in the laboratories of Romanian translators. It is the term in the opening of the entire Homeric creation, $\mu \tilde{\eta} \nu \imath$ (N. $\mu \tilde{\eta} \nu(\varsigma)$. It seems to be a simple word, posing no translation problems, especially in so far as Romanian, like many other Balkan languages, inherited it as such exactly from Greek: "mînie" [anger] ${ }^{4}$. In reality, as in the case of any term in the semantic area of affects, its meanings are very rich, finely nuanced and extremely dynamic in the linguistic and extra-linguistic contexts of their usage. ${ }^{5}$ For the signification in the Homeric text, a translator with a deep insight of the fine nuances of affective vocabulary-we refer to Mihai Eminescu - considers that minia [anger] is primarily a cerebral activity, and only secondarily an affective one, which could not have suited the attitude of Achilles, the warrior by definition, not prone to spiritual profoundness, but rather to instinctual reactions. The Greek hero lived "in sorrow", a state closer to the voice of the heart, therefore the rendering proposed by the Romanian poet is:

\footnotetext{
${ }^{4}$ We will not insist here on the history of the word in Romanian. Instead, we remark the fact that the famous "lists of Homeric words identifiable in our language" (id est: Albanian, Bulgarian, Croatian, Macedonian, Serbian, and others)—lists that circulate especially in the virtual electronic media but are taken from the academic treatises of linguistics in the respective countries, as a certificate of oldness and hence of nobleness-begin almost systematically with this word. Ismail Kadare uses it in the speech of some of the characters in his novel Dosarul $H$ [The File on $\mathrm{H}$ ], as emblematic for the conflicts marking the millennial history of his people (cf. Bârlea, 2015b, p. 46-49).

${ }^{5}$ For the characteristics of this semantic field, cf. Stoica (2012).
} 
Supărul cântă-mi-l, muză... (M. Eminescu, 1877) ${ }^{6}$

[Of sorrow sing to me, muse...]

N. Georgescu appropriates this term, showing that the Latins, too, translated the respective phrase by Achile furens (as well as Hercule furens). In fact, in his commentary, the modern exegete and translator admits that Lat. furor does not contain zăcășenia [the melancholy] (zăcăşia, in the dictionary of Hasdeu) characterizing Achilles in those moments. In addition, Rom. furia has a different stress (tending towards a double stress). Despite all these, he uses it in his version, as shown above, qualifying it with an attribute so as to emphasize Eminescu's idea of an instinctual manifestation.

Is the correct rendering of such a word so important? Of course it is, since-we have to stress this again -it represents the very starting point of the beginning of the Iliad and of the entire Homeric work. The opening word bears the entire thematic weight of the epic. It is not only the Prooimion, not only the first great linear compositional unit (between the two, "the Anger of Achilles" and "the Will of Zeus") that have as a theme-term the idea conveyed by this word, but the entire poem lies under force of its signification. The Iliad is the poeticised history of a war, and a war is always the story of a great sorrow. Consequently, the translation of this word is very important in the languages of the peoples who want to appropriate Homer in their national language and culture ${ }^{7}$. The question that has generated these considerations may, however, receive another, more accurate answer: all the word and their combinations in the text are important in their particular way. As far as we can reconstitute it, the process of forging the versions under study here shows that words of relatively lesser importance caused great turmoil in the minds and hearts of these master craftsmen of the word. The problems of selection concern not only the terms referring to the divine or human characters and the accompanying epithets, not only the key terms, but any other kind of words in the text ${ }^{8}$.

When the same Romanian translator resumes, in time, the version realized initially, even the terms considered by readers as models of adequateness in the Homeric texts are changed: strigăt [cry] is replaced by chiot [shriek], ucigătorul [deadly] by crîncenul [fierce]; pocni [clamoured] by zăngăni [clattered] (GM). It is scrupulousness and an ever better knowledge of the original that determine such successive substitutions. This clearly shows a never fully satisfied desire for the exact rendering of the Greek terms, for poignancy in Romanian and the unfailing observance of the number of syllables required by the verse. The above examples are taken from GM-I, XVI, and the latter (XVI, 115) succeeds in concomitantly resolving both the euphony and the integrity of the hexameter in the version of 1928 , as compared to that of 1920.

All these phenomena are absolutely explicable in any translation of this kind. The differences of culture and civilization, accentuated, as we were saying, by the enormous temporal distance between the

${ }^{6}$ M. Eminescu translated in the original metre canto I, vv. 1-18 of the Iliad around the years 1877-1878, cf. B.A.R., Mss. Rom. 2281, f.a., cf. also Mss. B.A.R. 2306, 96; 2308, 1. The text entitled Din Iliada [From the Iliad] was published by D. Murăraşu, after more than half a century, in the journal "Făt-Frumos", Suceava, VII, no. 3-4, 1932, p. 118, then was included by Perpessicius in the volume of posthumous works and annexes of the monumental series M. Eminescu, Opere [Works], vol. IV, 1952, p. 515, with the author's variants (seven pages from the manuscript poem 2266 only for the first five verses of the Iliad!) and with the editor's notes in Eminescu, 1958, p. 597. In the same volumes and with the same distribution of the material are also the 18 verses translated under the title Din Odisseia [From the Odyssey], representing the beginning of the respective poem.

${ }^{7}$ We do not propose to act as exegetes here, but from the perspective of traductology, we should remark on the very particular signification of the word in the mentality and speech of the Homeric world: $\mu \tilde{\eta} \nu \iota \varsigma$ means "divine, funereal wrath", and Plato enumerates four variants of concrete manifestation (provoked by Apollo, by Dionysus, by the Muses, by Aphrodite or Eros, cf. Plato, Phaidros, 244a-245c). The first verse of the invocațion in the Iliad is the only place, in the entire Homeric lexical corpus, in which the term is used to express an emotional state attributed to a mortal. The term for mortals was ó $\rho \dot{\eta}^{\prime}$ (Lat. ira), in the Homeric language. Otherwise, the theme of anger was frequent in the epics circulating in the period. Even in the Iliad, IX, 520 sqq., the old Phœnix tells the legend of Meleager, the Ætolian who, because of a family conflict, refused to participate in the war against Curetes, leaving his fellow citizens in Calydon prey to disaster.

${ }^{8}$ Small variations of orthography, etc. occur even in the reverential borrowings, see the commentary in DS-I, I, 1 . We have not dwelt on other various attempts, some of them fully deserving. 
two languages, the differences of lexical inventory and, not least, the specific lexical organization of the Homeric text, in which the rigours of the formulaic style generate only one of the difficulties, all lead to the approaches we have pointed out in these pages.

c) Lexical creativity, somewhat justified in 1837 and 1876, becomes embarrassing in Murnu's versions between the years 1906-1940. The freedom of association of productive Romanian affixes (-ime, $a t,-o s$, etc.) and of nominal and verbal flexion causes the so-called "fabrication of words" ("language enrichment", Eftimiu, 1996, p. 277, 287, and others): sfädălimea2 [the quarrelsomeness], greimea [the heaviness], gîtoase [long-necked], gîtar [neck cover], luptaciu [fighter]; gîfuind [panting], sfetit; a se oşti [en-arm oneself], a se ingloti, and others. Such words as pulpar [thigh-plate] and brăţar [arm-plate] (GM) are created, probably after the model of pieptar [breast-plate]'. The same critic provides an inventory of the semantic inadequacies resulted from forced morphological-syntactic structures, such as ahei inarmaţ $i$ in aramă [Achæans armed in copper]; voinic în vrere [sturdy in will], with pleonastic effects, with inherent ambiguities and obscurities.

d) Rare words can be useful when meant to render a concept rarely used in Romanian, such as cronid, harite etc. Unfortunately, a lack of measure sometimes makes itself felt here, too, cf. ostrov for 'insulă' [island], mertic for 'parte' [part] and so on. The risk of using such terms increases due to ignorance as to their exact meaning: the Romanian strămurare means 'țepușă [spike], possibly iron-tipped, with which Romanian peasants used to drive cattle (DLR, s.v.), so using it to mean 'suliță' [spear] or 'lance' is a risky licence ${ }^{10}$.

e) This brings us to the most frequent source of lexical selection in the Romanian versions of the Homeric texts-archaisms, regionalisms and, at the opposite end, neologisms. The first two subcategories are justified by the archaic and rural character of the translated poems. Even the most ardent supporters of the idea of urbanity, aristocratism, elevation and perennial nature of Homer's world and language-it is the case of G. Murnu and C. Papacostea-acknowledge the resourcefulness of the inexhaustible source of ancient folk vocabulary: văzduh for cer [sky], slobod for liber [free], crai for rege [king] or print [prince] and others - at GM; barem [at least], încalte, măre, mîhnire [sorrow], pricinaș [quarrelsome], tînji [yearned] and others - at CP, not to mention coabe [jinxes], găzdoaie [hostess], haram, indămînă [handy], scaldă [bathes], tîndală [dimwit] - at GC. These can be justified by the poetic synonym preferred to the term in current use or, in some cases, by the different number of syllables, an important element in versified translations. Others, however, such as abraş, aman, deliu, dihai, mehenghi and others do nothing but obscure the text. I. Caragiani was originally a folklorist, G. Murnu also criss-crossed the country in search of original folk texts; both knew well the Romanian regions from the Pindaric Mountains to the Western Carpathians, just as all the others were had in-depth knowledge of the stock of Romanian folk literature, as well as of the written chronicles and religious writings. The problem consisted in sifting of the words most appropriate to the context in both languages, as well as in achieving clarity and musicality in the target language.

In the interwar period, the every-day and literary Romanian language had reached the apogee of their development, due also to the flourishing of a literature well-connected to the contemporary pace of universal culture. But the ever present challenges of the Homeric text were apace with the times. Consequently, the desire to use the original metre involved resuming the cycle of the quest for "the appropriate words" through all the strata and stages of the Romanian language, as well as the personal fructification of the diverse means of lexical creation. This explains such terms as zeime [god-swarm], pețitorime [suitor-horde],

\footnotetext{
${ }^{9}$ N. I. Herescu affirms that such invented words would not represent a major fault if they were artfully crafted, "that is, æsthetically and in conformity with the spirit of the language” (Herescu, 2011, p. 384). The argument that Eminescu, too, uses obräzar [cheek cover] does not hold, beyond the fact that the poet really created new words. In this case, the term was already in existence in the Romanian apicultural register. In rare literary texts it is attested at I. Budai-Deleanu (v. 5841): "Cesta vinde-obrăzare viclene/This one sells sly cheek covers” (J. Byck, 1953; cf. brățări viclene [sly arm covers], Gh. Cardaş, 1925).

${ }^{10}$ We have not taken into consideration here the rare words in the Greek text itself. For example, in Od., VI, 625, Gr.

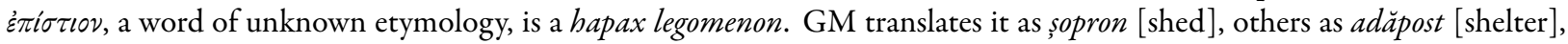
etc. (as does not seem to be a covered construction). It is the hangar for sheltering the vessels on shore, cf. Bailly (1950, s.v.).
} 
pricinași [quarrelsome], alergăreața (plută) [the running one (raft)] at C. Papacostea. Such words helped form the dactyls, the spondees, and trochees necessary to the hexameter succession in the Romanian variant (cf. Ioana Costa, in CP-O, ed. 2013, p. 7-9).

Eugen Lovinescu ardently sustained his conception regarding the loss, in the course of time, of the ancient æsthetic values (cf. Teoria mutației valorilor [The theory of the mutation of values]), and so, according to the Romanian classicist, even if the Homeric poems were comparable to children's fairytales and legends, which would justify the use of the proper vocabulary, it seemed to him appropriate that this should be impregnated with terms from the modern world for which he undertook the translation of the Odyssey: adunare [assembly], bunuri [goods], cadă [tub], capac [lid], cupă [goblet], a lustrui [to lustre], judecător [judge], minge [ball], oraş [city], a pierde dreptul [to lose the right], planuri [plans], rețele [networks], sală [hall], țară [country] and others.

f) Finally, especially for metrical reasons, some familiar words, otherwise clear and adequate to the respective morphological-syntactic structures, are used in aberrant, agglutinated forms-most of the times, without taking into account the syntactic inversions and dislocations to be expected in a poetic text: pierinecat [died-drowned] (GM-Od, IV, 681), Minerv-atunci [Minerva-then] (IV, 1064), i-o peșteră ['tis a cave] (XIII, 144); se arătă potriva zeilor [he showed himself'gainst the gods] (CP-O, XII, 202); din plutentrarmeaz-o [in rafts en-arm it] $(\mathrm{I}, 267)$.

g) The imitative words, phatic particles and expressions, imprecations, etc., frequent in an epic structure of ample dimensions that had originally relied on the effects of the oral storytelling by the rhapsodists or aoidoi in front of a participative audience, constitute the express purpose of some sentences in the preface of Heliade Rădulescu and the explanatory notes of C. Aristia (CA-I, p. IV). The oral character of the style imposed the use of some interjections and forms of address practically impossible to find in the formal registers of a language. Maybe some $o$, ehei, vai, ah could fit the requirements of elevated style. However, not even these morphological classes, so unheeded among the grammatical categories, are devoid of logical-semantic value or syntactically limited. Quite the contrary, their pragmatic, suprasegmental, contextual power of signification may well enrich the charge of an enouncement. In this light, there is little wonder that the reactions of the experienced readers of the Romanian translations were very diverse, ranging from praises to objections to the colloquial, even trivial expressions encountered in the Romanian translations: aoleo [woe me] (IC); olio [ouch] (GC); ptiu [pshaw]; (un) buideo (năpraznic) [(a) (blustery) boo], ducă-se naibii [to hell with it] (GM).

Utilized with measure and flair, such uncouth elements, as well as the unavoidable "imitative articulations" (IHR) can contribute to colourful effects or musical variety and dynamism in the translated text. The verses sound colourful, fluent and elegant even when such lexical items are packed in a single couplet:

$O$, zei, ia uite minunea ce-ajuns-am s-o văd eu cu ochii!

Zău că Troienii cei trufaşi pe care-i ucis-am odată...

[Oh, Gods, come see the wonder my eyes have come to see!

In truth 'tis that the proud Trojans once I did kill...]

(DS-I, XXI, 54-55)

Sometimes, when we encounter samples of vernacular expression, it is difficult to distinguish between necessity and voluntary choice, between fidelity towards the original and stylistic creativeness adapted to a certain kind of sensibility from another time and place of reception:

Douăsprezece din iepele mîndre, și bune catîrce,

Tari la dîrvală, nu încă strunite: la ham le-aş cam pune!

Astfel grăi, iar aceia rămaseră paf...

[Twelve of the fair mares, and good she-mules

Fit to be burdened, not yet broken in: harness them methinks I would 
Thus he spake, and those remained floored...]

(Ds-Or, IV, 636-638)

It is true that such a discourse is supposed to characterize Noemon, son of Phronios of Ithaca, one of the "obraznicii pețitori" [brash suitors] (CP) gathered at the court of Odysseus, where they broke all the accepted norms of hospitality. The lack of urbanity is also verbally manifest in the curses and expletives proffered by almost all the suitors, permanently under the influence of the wine drunk without restraint from the cellars of the palace they have occupied, when they hear that Telemachus is not at the country, on the pig farm or in some sheep pen, as they all believed, but had sailed on Noemon's ship, borrowed from Antinous, towards Pylos, the city of the wise old man Nestor. This time, it is Antinous himself, one of the more urbane princes, who expresses himself uncouthly:

\section{...Rău i-a fi și i-a prinde! Ci Zeus să-l bată \\ Și să-l doboare virtutea nainte să-și ia bărbăția! \\ (Ds-Or, IV, 667-668)}

All these aspects, fleetingly noted here, equally relate to the problems of contrastive-typological grammar and to the translator's conception regarding the act of rendering meaning. I. Caragiani was a professed adversary of lexical innovations and neologisms, but he cultivated the oral character of the style, while observing the rigours of the text. To him, $\gamma \lambda \alpha v x \tilde{\omega} \pi \iota \varsigma$ meant neither "cu ochi strălucitori" [with shining eyes] (CP), nor "cu ochi verzi" [green-eyed] (DS) or "cu ochi albaștri” [blue-eyed] (GM), but "cu ochi de cucuvea" [owl-eyed], in the literal sense of the Greek term ${ }^{11}$. By contrast, to G. Murnu no innovation seemed too risky for rendering the spirit of the text and especially what he considered as epic inventiveness: Elena was înciumată [plague-struck], Hermes - pîndăreț [poking]; even Aurora, well-known for her "degetele trandafirii" [rosy fingers], is given a "văl șofraniu" [saffron veil] in his text (GM-I, XIX, 1) - meaning yellow (?). However, he says elsewhere: se ivise zorii trandafirii [the rosy dawn had appeared] (GM-Od, V, 301-302). It is true, however, that the lexical-grammatical delights he alone indulged in often led to spectacular results. We shall have occasion to see that the complex stylistic structures of the type "dormind la porțile visului" [sleeping at the gates of dream] (Od., IV, 1080), become in Romanian

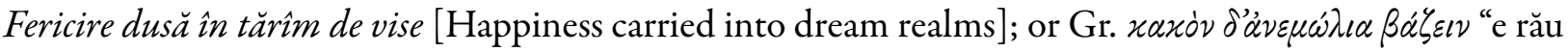
să spui lucruri duse de vînt" [it's bad to say things borne by the wind] (Od., XI, 464) becomes că-i prost vorbitu- $n$ dodii [as vain is long-drawn out speech].

As usual, the middle path is sought by Cezar Papacostea, while the fair yet savoury one by Dan Slușanschi.

\subsection{The autochthonization of the Homeric texts}

2.3.1. In many difficult situations of rendering the Homeric texts in modern languages, salvation came by applying the principle of local naturalization, widespread all over Europe, especially during the period of Romanticism. The principle persisted in the "small" cultures of South-Eastern Europe and, sporadically, in other areas until the end of the $20^{\text {th }}$ century. For the translators from the literature of ancient Greece, the fashion was superposed upon an older one-Latinisation, practiced ever since the end of Antiquity ${ }^{12}$,

\footnotetext{
${ }^{11}$ The epithets and metaphors based on the zoological system of reference are customary in the Greek epos, cf. Hera, the wife of Zeus, with the cognomen $\beta 0 \tilde{\omega} \pi \iota \varsigma$ "cu ochi de vacă" [cow-eyed] (Il., I, 551; III, 144 and others); the same Hera can have

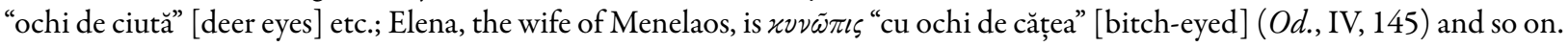

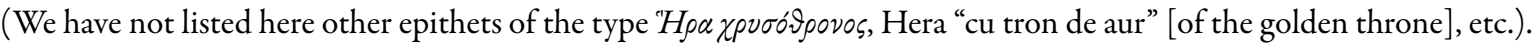

${ }^{12}$ It is known that the first monument of literary Latin language was the translation realized by Livius Andronicus from the Odyssey (about $270 \mathrm{AD}$ ). The Latin versions multiplied in the republican period and especially in the imperial age, so, by the end of Antiquity the Homeric poems had become not only a literary model, but also a common cultural asset, circulated among the world's peoples in the Latin version.
} 
continued throughout the Middle Ages and later in modern times ${ }^{13}$, when translations were no longer realised in Latin, but in the national languages, although certain conceptual and lexical areas continued to be rendered in a Latinate fashion, adapted to the local specificity. From this melange resulted particular forms of some large lexical categories, some of them very remote from the spirit of post-Mycenæan Hellas. In fact, in some cases in the history of Romanian translations, the entire text was treated thus, as the general traditional local atmosphere was considered likely to suggest the Homeric one in a veridical manner.

2.3.2. George Murnu, Cezar Papacostea and especially E. Lovinescu theorized their chosen approaches to translation, each of them based on different categories of arguments. G. Murnu provides two rationales in favour of his translation endeavour, in general, and of the procedure of autochthonization, in particular. Since Romanian culture is among those that do not possess a great national epic of their own, the translator-who, by virtue of his origin, belonged to both cultures, Greek and Romanian-thought it possible to fill this blank by naturalising the Homeric poems, an achievable feat, theoretically speaking, due to their universality and their appurtenance to a Balkan stock of which Romanian spirituality is part. The second claim (id est: motive, argument) formulated by the translator, who devoted his life to rendering the Homeric work into Romanian, is at least as ambitious as the former: the Romanian naturalisation of the Homeric poems would give him the opportunity to contribute to the process of enriching and increasing the expressivity of the Romanian language ${ }^{14}$. Interestingly, we should add that G. Murnu categorically rejects the idea of the popular and naive character of the Homeric epics, but the thickest vein in the reserve of Romanian language and mentality that he exploits in order to "enrich" Romanian, in the process of transfiguring the Hellenic oral epos, originates-as shown in the aforementioned examples-precisely from the folk areas, from the oldest, most rudimentary and hidden linguistic and folkloric manifestations of Romanian spirituality. The society portrayed by Homer surpasses in mentality, in the level of civilization and style of communication the middle estate of present-day receptors, as the "Homerologist poet" puts it, but in the text he (re)produces he does not hesitate to make the characters utter words and expressions specially collected from untilled areas of the Romanian language, see above, 2.2.g). Cezar Papacostea himself proceeds in the same manner, in his commentaries and his own version of the Odyssey. He expressed his conception about the translation of the ancient classics in the correct version of some platonic dialogues and it was to be expected that the translator should sustain the elevated style ${ }^{15}$. However, in the particular case of Homer, the recourse to the language of fairy-tales and legends,

\footnotetext{
${ }^{13}$ In fact, it was the tradition of commentaries in Latin on the Homeric poems that maintained the use of theonymy, anthroponymy, toponymy and other lexical groups (military terminology, that of civil and religious hierarchy, etc.) in Latin. Adapted at first in Le Roman de Troie (1160) by Benoît de Sainte-Maure, the Homeric texts were translated in Latin in the Middle Ages and the Renaissance by Italian and French humanists such as Leonardo Bruni, Carlo Marsuppini, Niccolò della Valle, Lorenzo Valla, Angelo Poliziano. Decisive for the Greek text and for the commentary in the Latin language circulating in the world were the editions realized by Demetrios Chalkokondyles (Florence, 1488), Aldo Manuzio (Venice, 1517), Adrien Turnèbe and Henri Estienne (Paris, 1554, respectively, 1566) and others. Cf. D. M. Pippidi, Introduction to GMD-I, p. 32-33.

${ }^{14}$ Acknowledging that the great creators and translators such as Dosoftei, Miron Costin, Dimitrie Cantemir, Mihai Eminescu and others had indeed decisively contributed to the enrichment and the crystallisation of the specificity of the Romanian language, G. Murnu expresses his satisfaction at having succeeded in what he had proposed, in his turn, to achieve in this sense: "...I have been studying for a long time the sources of the Romanian language, from the present and past, as well as from all the regions inhabited by Romanians, even from the most remote ones, where I have found a treasure of new words, and adding to this my own power of creation, I have compiled a vocabulary which, judging by the opinion of many, is maybe the most varied attained in the Romanian tongue... I have spared no effort... in conveying a Homer transfigured in such a way as to make it our own (our emphasis, P.G.B.), of our people, and, if possible, to bring it up to date better than in any other foreign language" (G. Murnu, Cuvintul traducătorului [The Translator's Foreword] to GM-O, p. 25-26). Murnu's confidence that he succeeded in endowing Romanian with "the most varied" vocabulary (it is self-understood that the term of comparison is represented by the texts realized by the previous Romanian creators and translators enumerated above, as well as by his contemporaries) was shared, in general, by those who considered that Murnu's Romanian version was superior to many in other languages (cf. A. Pârvulescu, Introducere [Introduction] to GM-O, p. 20; D. M. Pippidi, Introducere [Introduction] to GM-Od, p. 35 and others)

${ }^{15}$ The ideas formulated in the Preface to Plato, Opere [Works], vol. II, Banchetul [The Banquet]. Phaidon, București, Casa S,coalelor, 1935, were resumed in diverse studies published in periodicals.
} 
of Romanian folk proverbs, as well as to that of the chroniclers or the translators of homilies helps him forge the Romanian form of the twelve rhapsodies he translated from the Ionic-Eolic idiom. Or this meant not only lexical choices imposed by certain nuances in the original text, but also adaptations of onomastic or phatic terms, of realia and religious dogma, of mentalities and atmosphere, for that matter.

E. Lovinescu was by far the most categorical and pragmatic regarding the local naturalisation of the Homeric text. All the key concepts in the ideology of this critic and historian of Romanian literature and culture- "the mutability of values", "modernism", "synchronization", "the cultural moment" (the spatial-temporal setting), "the relativism of the perception of values", "imitation" - are reinvested in his translation theory. In the conception of the classicist converted to the critical study of modern Romanian literature, any artistic creation mirrors the civilization that generated it, being determined, in its turn, by the sensibility of its time and people, by their material conditions, as well as by their spiritual manifestations - religion, economic doctrines, politics, philosophy, etc. All these act in a unitary manner and anchor the work of art in time and space:

\begin{abstract}
„Odată cu timpul, partea vie, palpitul operei de artă se scutură, lăsîndu-i mai mult sau mai puțin scheletul, schema ideologică. Firele directe ale intuiției estetice rupându-se peste prăpastia timpului, trebuie să aruncăm, cu multă trudă și erudiție, punțile cunoașterii intelectuale și istorice...”

[As time goes by, the living part, the pulpiness of the work of art is shaken off, leaving behind its skeleton, its ideological schema. The direct strands of æsthetic intuition having been broken over the chasm of time, we have to reconstruct, with much toil and erudition, the bridges of intellectual and historical knowledge...]

(Lovinescu, Mutația valorilor estetice, quoted from Lovinescu, 2012, p. 31)
\end{abstract}

If people were able to create new æsthetic formulæ by imitating the old ones, this was due to their adaptation to the nationalspecificity, so long as the old models are possessed of a real power to radiate in time and space. With particular regard to the Homeric poems, E. Lovinescu thought that their æsthetic force can only be reconstituted through the compensating values of the specific thinking, sensitivity and national language into which they are transmuted. Such images as "Aurora cu degete de roză" [rose-fingered Aurora] or "Junona cu ochi de juncă" [the calf-eyed Juno] do not only fail to resonate with the spirit of the moderns, but they may also be offensive, since the socially determined system of reference has totally changed. Consequently, the whole or at least some of the essence of the old forms and ideas can touch the sensibility of the present-day recipient provided that a good translator finds the correct correspondences to the contemporary national system. In this case, what is important is not so much the formula of logicalsyntactic units, that is the choice between versified translations (in original metres or rhymed verse) and prose, but rather more important is the essence of the updating and local naturalization.

E. Lovinescu was also full of collegial praise for the translations of G. Murnu, despite the big differences between them in terms of thinking and creative practice, and, even more, despite the fact that the criticisms against his own translation were formulated by comparison with the achievements of his colleague who had already established a reputation in the domain. What confers value to the Murnu's versions of the Iliad and the Odyssey is primarily his verbal creativity, in a fertile competition with that of the Greek original. More exactly, the author of the The Mutability of Asthetic Values rightly considered that the popular vein of this creativity is what replicates the "atmosphere" of the original text, a concept frequently invoked in the debates among the translation theorists of the interwar period. Thus, in the dialogue between Odysseus and Dolos there appear expressions such as “fii liniștit despre asta" [rest assured about this]; "atâta răspunde- mi" [so much answer me] and others, which are "extracted from the very original genetic makeup of the Romanian language". From this point of view, Romanian, like other languages in South-East Europe ${ }^{16}$, is better fit to render the archaic and oral nature of the Homeric world,

\footnotetext{
${ }^{16}$ About the situation of transaltions in this part of Europe, where the tradition of the popular bards, carriers/creators of some epics of Homeric type, has endured until recently, cf. Bârlea (2015a).
} 
in comparison with the crystalized, "aristocratic" languages such as French or English. The Homeric heroes cannot be speaking like the marquises from the French royal court. Priam is less a "roi des rois" [king of kings] and more of a "moşule dragă" [dear old man]. Romanian is a language that still retains quite well a rural variant, "mirosind a lapte și caș" [smelling of fresh milk and cheese]. Therefore, Ion Creangă could have been a good translator of the Odyssey, if only he had known ancient Greek. This idea is derived from E. Lovinescu's conviction that the Homeric poem is nothing else but a fairy-tale, related, in its essence with Harap-Alb or other similar works:

"Lestrigonii, Ciclopii, Circe, Scila și Caribda sunt din rasa Spânului, a lui Gerilă, Flămânzilă." [The Lestrygonians, Cyclops, Circe, Scylla and Charybdis are of the same breed as Bald-Head, Frosty, Famished]

(Lovinescu, 2012, p. 336-337)

From the perspective of cultural evolution, which he had theorized in Istoria civilizației române moderne [The History of Modern Romanian Civilisation] (I-II, 1924-1925), both literary species cited herethe Homeric epic and the Romanian folktale-are popular artistic emanations assumed and shaped by a known creator, creations having the same type of ideational, psychological and æsthetic content, "fresh and naïve", which does not go beyond a childlike mentality.

The entire theoretical construction underlying the translation approaches to nativization is encapsulated in the following sentences of Lovinescu:

„Pentru moderni, poezia homerică nu poate avea decît valoare noțională; întregul element sugestiv, intregul zăcămînt emoțional de reziduuri ancestrale, pe care-l are orice limbă și pe care trebuie să-l fi avut cu deosebire o limbă proaspătă ca limba elenă, cu imagini și metafore vii încă, legate prin credințe multiple în senzație, întreaga această sevă bogată, colorată, care circula în poezia homerică a dispărut pentru totdeauna, pentru necunoscător, ca și pentru cel mai adînc cunoscător al limbii și civilizației elenice...

[For the moderns, Homeric poetry can only have a notional value; the entire suggestive element, the entire emotional repository of ancestral vestiges which any language possesses, and which a language so fresh as the Hellenic one must have had above all others, with its still vivid images and metaphors, linked to sensation through multiple beliefs, this entire rich and coloured sap circulating in the Homeric poetry has vanished forever, for both the neophyte and for the most adept scholar of the Hellenic language and civilization...]

...întrucît valoarea de sugestie poetică a Iliadei este pierdută pentru totdeauna, ... (ea) poate fi recreată, cu mijloace proprii și pe răspundere proprie, de traducătorii moderni."

[...since the poetic suggestiveness of the Iliad is lost forever, ...(it) can be recreated, with their own means and on their own responsibility, by modern translators."]

(Lovinescu, 2012, p. 334-337)

2.3.3. Before analysing systematically the measure in which modern Romanian translators dealt with autochthonization ${ }^{17}$, we should specify that the term under discussion covers two levels of manifestation:

1) The surface level, promoted only by some translators, consists in the local naturalisation of the system of beliefs, mentalities, attitudes, on the one hand, and of the references to the social and material organization, on the other;

\footnotetext{
${ }^{17}$ We insist on the fact that this phenomenon has not characterized only the translations into Romanian or those from the Balkans (versions in Serbian, Croatian, Bulgarian, Albanese, Macedonian, Slavic, etc.), but also the Hungarian or Eastern Slavic ones, and even those in western and northern Europe (French, English, Italian, Swedish, Norwegian and others), with the difference that, in the latter case, the process of "implantation", as it was called by the English George Chapman, a veritable founder of Anglo-Saxon translatology and Homerology, began around the end of the $16^{\text {th }}$ century and ended, in principle, with the end of Romanticism.
} 
2) The profound, diffuse and universal level consists in utilizing on a large scale of everyday vocabulary, of morphological-syntactic and stylistic-pragmatic constructions from living, popular, archaic national language.

\subsubsection{The local naturalization of spiritual and material values}

The most visible-and most striking, for the expert reader of the Homeric texts-were the adaptations undertaken in the sphere of religious belief, of mythology, superstitions, of the entire system of reference from the arena of man's relation with the supernatural, as well as with nature and the universe itself. The problem has been discussed ever since the first significant Romanian translations from Homer began to appear. The best-known attitude was expressed in the foreword I. Heliade Rădulescu wrote to C. D. Aristia’s translation of the Iliad, which he published in 1837. It would be easy to use proper names and epithets from one's one belief: Atotputernicul Dumnezeu [Almighty God], Dumnezeitul [The Godly], Îndelungrăbdătorul [The Ever-Patient One], Multmilostivul [The Merciful One], and others. But gods, heroes, customs and, implicitly, their accompanying epithets change over centuries and we may not use Christian names for pagan gods, whom we must somehow name according to the spirit of the time (Denalttunătorul [Thehigh-sky-thunderer], Noriîntărîtorul [The cloud-rouser], Ochiosul [The goggle-eyed]), as does C. D. Aristia (CA-I, p. IX). In fact, in CA we find a mixture of Greek and Latin names-Apolon, Ulis, Agamemnon, Nestor; Joe, Zea Juno, Zea Minerva - for which he created Romanian epithets by means of calque (argintarcatul Zeu [the silver-bowed God]; brațalba [the white-armed] Juno), total translation (näprasnicul [the frightful Polifem]), or direct loan (Phebu, Glaucopa).

The other breaker of new ground of the $19^{\text {th }}$ century, I. Caragiani, gathers his ideas about translation in the short foreword Cätre cetitori [To the Readers] from the prose edition of the Odyssey, 1876. Considering the Homeric texts to represent the "limba copilăriei poporului grecesc/the language of the Greek people's childhood", the Aromanian scholar decides that it was the popular language and that of religious books that could best convey them into Romanian, on condition that rare and obscure forms were avoided. Even more, he did not agree to personal interventions and inventions: "nici n-am stricat, nici n-am dres limba" [I have neither ruined nor mended the language], and he carefully avoided words he had not heard in popular speech ${ }^{18}$.

As for the rendering of the universe of religious beliefs in the Homeric texts, things are somewhat more complex. The gods, heroes, etc. bear their original Greek names, obviously phonologically and morphologically adapted to the system of the Romanian language: Zeus, Athena, Odiseu, with their attending epithets, quite closely followed: Cronide [Son of Chronos], Olimpicul [The Olympian], respectively cea cu ochi de cucuvea [the owl-eyed], divinul [the divine], multîncercatul [the much tried one], multiscusitul [the skilful one], while in the abounding footnotes he also gave the Latin equivalents-a tribute paid to the European fashion, still active at the time, and, most certainly, to the professed didacticism of such translations. In fact, in the case of epithets from the religious sphere, Caragiani translates the adjective diós by "dumnezeiesc" [godly], which represents a first concession made to autochthonism proper. Only the editor of 2011, Ion Acsan, finds it appropriate to make alterations in the original text, translating the Greek term by "divin" [divine], which is polysemantic, or by "zeiesc" [godlike], more pronouncedly pagan. Considered as anachronisms, several such items are changed: biserică [church] by templu [temple], etc. Some are left unchanged: O, Doamne! sfintul oraş [Oh, God! the holy city], sometimes replaced, however, with sacru [sacred]; prorocire / prorocit / proroci [prophecy / prophesied / prophets]; fruntasi $i$ și sfetnici [headmen and counsellors], and others. If we also add to his personal choices, uncorrected by modern editors, the profound stratum of popular speech avowedly adhered to, from the very beginning, by the founder of the speciality department at the university if Jassy, we can say that the IC version represents a model of well-balanced autochthonism.

\footnotetext{
${ }^{18}$ The translator, philologist and linguist of Jassy I. Caragiani declared that he had enlarged on his on his ideas in the volume translated from the Iliad, "under print" in 1876 (Caragiani, Către cetitori [To the Readers], in IC-O, p. 9). Unfortunately, that volume never came out.
} 
Among the native forms utilized by the ardent folklore collector and philologist Caragiani in his Odyssey, we enumerate:

— daurita Afrodită [gilded Aphrodite]; OstrovulEolin, în palatele Crivățului (din Thracia) [The Hellenic Isle, in the North Wind palaces (from Thrace)]; Baba Hîrca [Witch Hag];

- nădăjduiesc să săvîrşești [I hope you will accomplish]; Haide, femeie! [Come, woman!]; Mamă-ta [That mother of yours];

- straie, merinde, nuri [attire, victuals, charms]; din fitil [from the fuse].

Adapted proverbs and sayings:

- tot ce-i drept este bun [all that is fair is good]; pentru oamenii cei răi și chezășiile sînt rele [for bad people even vows are bad], etc.

After these hesitations and evident search for a balance between literary and popular-archaic language, between observing the Hellenic spirit and the Romanian naturalisation of certain human realities and aspirations, we would have expected the century of modernism to be decisively oriented towards the former working manner. In Romanian culture at least, things did not work this way. The period of the great achievements in the domain of translations from the Homeric texts also effected the transformation of these "anachronisms" into a principle of approaching the Homeric text. The Latinate names of gods, heroes and other characters, of some cities, waters or mountains complicated even more the process of autochthonization proper, manifested in all its aspects. G. Murnu, the most prolific and most devoted to the Romanian naturalisation of the Homeric texts, has so many such adaptations, exercised in his numerous fragments, editions and integral recreations, that citations would appear almost superfluousthe pages above already contain illustrative examples in this sense. Joe is taken from CA, but Ulise is taken directly from the Western humanistic tradition, as well as Neptun, Vulcan, Minerva. The epithet Cronides [Son of Chronos] becomes Saturnianul, since, just as Zeus is the son of Chronos, his Latin correspondent, Jupiter, is the son of Saturn (GM-Od, I, 68 and others). Eriniile [Erinyes] are Furii [Furies], and Harpiile [Harpies] are Vîntoasele [Windy Ones] ${ }^{19}$, these being cases of direct translation. On the other hand, the same Joe becomes Dumnezeu [God], at least in the formulæ of consecration: Păzească Dumnezeu [God forbid] (GM-Od, I, 543); Dumnezeu m-ar bate [God would chide me] (GM-Od, II, 188) and others. The term Domnul [Lord] is used in a theological sense, but also in a lay-administrative sense (să fie domn în țară [be lord of the country], GM-Od, I, 541; e domn peste popor [is lord over the people], I, 562); cf. also Domniţa Nausica [Princess Nausicaa] (GM-Od, VI, 19).

In the same semantic area, templul [temple] becomes biserică [church], and all that is sacru [sacred] becomes sfint [saint] —as at CA or IC. The reactions to such adaptations were fully justifiable. Just like Heliade Rădulescu before him, V. Eftimiu considered such forms as a profanation of the recipients' faith. Biserica, Sfintul și Domnul [The Church, the Saint and God] belong to Christians; Templul, Divinul, Zeus [The Temple, the Divine, Zeus] were Homer's (Eftimiu, 1996, p. 251). As for the translation of epithets/names formed by antonomasia, we can supplement those above with innumerable others. Ares, the god of war, is Războilă [Warlike], and Vînturile de Miazănoapte [North Winds] become Borilă [Borealis]. In this way, as V. Eftimiu notoriously said, Zeus could have become "Trăznilă" [Thundery], and each Homeric hero could have been equated to a character in the folktales of P. Ispirescu.

Technically speaking, the procedure is classifiable neither as translation nor as linguistic calque, being a kind of forced local naturalization of the concepts thus named. The whole range of such methods was deployed on a large scale in the translations of the interwar period.

At this level, of the forms of address and of the diverse formulæ of consecration, G. Coşbuc freely remakes the ambience of the rustic Romanian faith, through such expressions as Domnul stie cum! [God knows how!], Ferească Dumnezeu! [God forbid!], Ferească sfintul!, l-au stins din lume sfinții [the saints snuffed him off the world], frați de cruce [cross-sworn brothers], and others.

\footnotetext{
${ }^{19}$ Textually, harpyai means "predatory".
} 
The divine and human epithets or hierarchical tiles, the surnames used as names, by metonymy, belong to the same trend of local naturalisation. In the verses of G. Murnu, Agamemnon, the kings of kings, as well as Priam, the king of Troy, are crai [princes], the wise Nestor is Moss Nestor [Father Nestor], Polipoides is Luptaciul [Fighter], and Stenelaos is called bădie [uncle] by Diomede. Elsewhere, both Agamemnon and Zeus are called impăraţi [emperors], and the gods' council is called divan [chancellery] (GM-I, XI, 5).

C. Papacostea works in the same way, looking for equivalents for official titles, hierarchies, socialpolitical and religious office titles in the Romanian chronicles and the national literary folklore: Dumnezeu [God], zîna zînelor [fairy queen]; chelăriță [housekeeper], paharnic [wine bearer], voievozi [voivodes], crai [princes], stäpini i [masters], and so on. In fact, in such situations, even the translators into the languages of Western Europe, already shaped and refined in their own epics and poetry, resort to a certain manner of autochthonization, the level of their culture and civilization. In the Alcinous' speech addressed to his leading counsellors, in $O d$., VIII, 97, we find these formulæ:

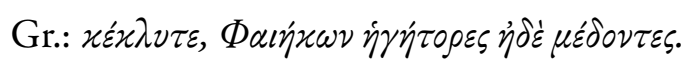

Rom.: Ian ascultați, voievozi şi stäpinini ai noroadelor voastre [Lo, listen, ye voivods and masters of your peoples] (CP)

Fr.: Doges et conseillers... (VB)

We notice that Victor Bérard, too, highly appreciated by the readers of the time, though considered by classics philologists to have strayed too much from the original ${ }^{20}$, correlates the names of office either by spatial and temporal adaptation or by generalization. In the Romanian versions, local adaptations were almost unanimously cultivated, even by the translators categorically opposed to onomastic changes or changes of any kind:

Ascultați, voi fruntaşi și sfetnici... [Listen, you headmen and counsellors...] (IC)

Luați aminte, fruntași și sfetnici [Hark, headmen and counsellors] (EL)

Luați aminte, voi fruntași și sfetnici [Hark, you headmen and counsellors] (GM)

Mă ascultați, voi, Feaci, căpeteniișisfetnici de seamă [Lend me your ears, you Phæacians, chieftains and high counsellors] (DS)

The correspondences proposed by C. Papacostea are somewhat better fitted into the text and naturalised. For a form of address such as Gr. $\gamma \alpha i \delta \mu$ ' $O \delta \nu \sigma \sigma \varepsilon \tilde{\nu}$, experienced researchers compare the Romanian and French versions:

\section{Luminate impărate [Enlightened emperor] (CP) \\ Noble Ulysse (VB)}

Calypso, called by the rhapsodist "the goddess of goddesses", is transformed into a fairy-tale character by $\mathrm{CP}$, which is not the case at V. Bérard, who uses, however, a kind of superlative considered to belong to popular use, even in the language of Molière:

$$
\begin{aligned}
& \text { Gr.: } \delta i \alpha a ~ \vartheta \varepsilon \dot{\alpha} \omega \nu \\
& \text { Rom.: zîna zînelor (CP) } \\
& \text { Fr.: cette toute divine (VB) }
\end{aligned}
$$

Eos "cea cu degetele trandafirii" [the rose-fingered], called Aurora in the Latinate versions-French, Romanian, and others-, becomes Zîna Zorilor [Dawn Fairy] (CP). The Greek king, such as Alkinoos or Menelaos, is $\beta a \sigma i \lambda \varepsilon v$ s, which becomes crai [prince] in Romanian (CP and others). Eumelos, Odysseus'

\footnotetext{
${ }^{20}$ The very edition of 1924-1925, an attempt at "reconstructing a primal Odyssey" is considered as not recommendable today, as being the fruit of an overflowing fantasy, cf. Ds-Or, p. 403.
} 
brother-in-law and father to Iftimia, is Evmel Împărat [Evmel Emperor] (CP), like "Roșu Împărat" [Red Emperor] or "Negru Imparrat" [Black Emperor] in Romanian folktales. Queen Arete, the wife of the

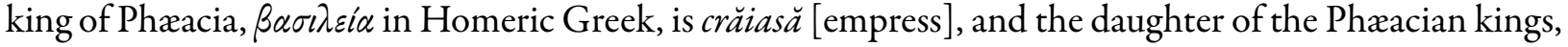
Nausicaa, is a domniță [princess] (CP). The divinities embodying the winds are in their turn, Boreas, but also Crivăţul [the North Wind], Austrul [the East Wind], etc., at the same CP.

The same method is also used for other characters of the same rank. Hera addresses her husband Zeus thus in $O d ., \mathrm{I}, 45$ :

\section{Gr.: "Y $\pi \alpha \tau \varepsilon \varkappa \rho \varepsilon \iota 0 \nu \tau \omega \nu$ \\ Rom.: Inălțate Impărate [High Emperor] (CP) \\ Fr.: Suprême Majesté (VB)}

While the renderings in the modern languages of the "great cultures" are relatively correct, albeit "colourless", the Romanian ones are considered by some Romanian philologists to be beautiful, natural, inspired, without having lost too much in terms of accuracy (Herescu, 2011, p. 145-146).

The apogee of this fashion in the translation of the Homeric texts was represented by the versions of GC and EL, each in its own way, considering not so much the distance in time, as the particularities of the poetry and prose forms, the original used and the conception about the literary language. As shown above, in the translation EL-O, Zeus is sometimes Juppiter, sometimes Dumnezeu [God], with the entire semantic area of beliefs and superstitions being treated in the same manner, from Doamne [Dear God] (p. 16), Slăvite Doamne [Holy God] (p. 33); mărite Doamne [Almighty God] (p. 39/41), Dumnezeu [God] (p. 39), vai, Doamne [Oh, God] (p. 45), Ferească Dumnezeu [God forbid] (p. 36, 36, 40), Cel de sus [The one in heaven] (p. 53), pînă la zîne [to the fairies] (p. 45), zînă dragă [fairy dear] (p. 57), zîna [the fairy] (p. 58), moșule dragă, maică, mătuşă, feții mei [dear old man, mother, aunt, my sons] (p. 37).

He is adamant in his opinion that the Homeric poems represent instructive reading for children and adolescents, just like national folktales ${ }^{21}$, which he uses heavily as a lexical source, deploring again, as he had done in his essay The Mutability of Esthetic Values and in other studies, the paradoxical incapacity of the evolved Western European languages to render such "naïve and primitive writings"22. E. Lovinescu's theory is better argued for and more seductive then the actual prose rendering of the Odyssey in Romanian. The translator naturalized and adapted it to what he considered to represent the specificity of the national sensibility of the period, but he did not create the "suggestiveness" he discussed so much. Instead, the one who succeeded in achieving it was the poet G. Coșbuc, who followed an intermediate German version, relatively "cold" and undoubtedly scientific (due also to its being full of explanatory notes), which helped him fully grasp the content of the Greek original, inaccessible to him for a direct reading. The version of EL was described as a "a literary, rather than a philological work" (Traian Costa, "Note asupra ediției" [Notes on the Edition], in $\mathrm{EL}_{\mathrm{L}} \mathrm{Or}_{5}$, p. LV), while the version of GC was said to represent a model of "fidelity and beauty", a "splendid" new text based on the Homeric epic ( $\mathrm{GC}-\mathrm{O}$ ). This was because, alongside the substitution of theonyms (Zeus/Dumnezeu) and the phonological and morphological adaptation of the other onomastic references (Ermia for Hermes, etc.), G. Coșbuc took over from the Romanian model of I. Caragiani all the other lexical areas, expanding them and impregnating the Homeric text with an extremely rustic Wallachian flavour:

\footnotetext{
${ }^{21}$ In Prefață [Preface] to the $1^{\text {st }}$ edition of 1935, E. Lovinescu confesses that he derived this conviction from old German pedagogy (EL-O, p. 9).

22 "French translations realised by savants and even by the great poets [with reference to V. Bérard and Leconte de Lisle, respectively] are far from rendering the savour of the ancient text: the French language is precise, logical, saturated by elegance and modernity, therefore its instrument distorts the rural character of the Homeric world and transforms the manor of Ithaca into the court of Versailles... Completely richer possibilities are offered by the Romanian language, rustic and patriarchal in its essence, being still in the process of forming and therefore open to possibilities of verbal creation and malleability. Such an instrument made it possible to attempt the unstiffening of the Homeric flexibility from the French style, solemn and courtly, so as to render it in a shepherd-like language sounding sagacious and persuasive, mellifluous and candid" (EL-O, Prefață [Preface], p. 10).
} 
— forms of address: bade [uncle], bunică dragă [grandmother dear] etc.

- specific terms referring to autochthonous realia: cergă [woolen counterpane], opinci [peasant sandals], (lină) țigae [prime wool].

- expressions reflecting a rural lifestyle, as noticed to the exegetes of the version: Telemachus sleeps in the cerdăcel [little porch] and takes his arms up to the culă [bartizan]; a țol de lînă [woollen rug] and a velință de in [linen counterpane] are laid for Odysseus; a ștergar curat [clean cloth] is laid on the table; Nausicaa spală ii și läicere [washes embroidered blouses and hearthrugs]; the maid-servants cîrpesc straie [mend togs]; Nestor sits on a laviță cioplită [carved bench] etc. (Cazimir, in GC-O, p. XV-XVII).

- the epithets, attitudes and actions exclusively specific to the attributes of the Greek gods are rendered by Romanian idiomatic phrases: Penelopa is "burduf de vedenii" [crammed with visions]; Menelau "are gînduri coapte" [has ripe thoughts]; Odysseus' companions are "gata de măciucă” [ready for bludgeon $]^{23}$.

\subsubsection{Everyday vocabulary and grammatical-stylistic constructions with a local tinge}

With these, however, we have returned to the analysis of the general vocabulary of the Romanian versions.

a) Nothing of what can configure the system of popular variants, if one can conceive of such a system, has remained untried in the translations from Homer realized within the framework of the Romanian language. We are going to enumerate here only a few lexical-grammatical subcategories:

- Popular, archaic, regional terms, constructed according to the mechanisms of compounding, derivation and conversion typical of popular use: coabe [jinxes], codruleț [thicket], fărtați [brethren], fiștecare [each one], găzdoaie [hostess], îndămînă [handy], prăpăd [havoc], tîndală [dimwit].

- Folk regional phrases and expressions: a avea saț [to be satiated], a pune la cale [to be plotting], a da gata [to do in], a lua la vale [to tumble downhill], a face ispravă [to do well]; legați-l cobză [to tie hand and foot], bată-lvina [goddamn], lovit de streche [moonstruck], intr-o ureche [madcap].

- Metaphorical constructions from the inventory pertaining to rural Romanian mentalities: a prinde $\hat{i n}$ ițe [to entangle in threads], a merge cu vorba [to spread word], a ieși cu plinul [to meet with full luck], a strînge la pungă [to fasten one's purse] („a înșela” [to cheat]).

Practically, at GC, as well as at EL and only partially in CP, the Olympian gods speak the peasant idiom, like the characters in the fairy-tale Povestea lui Harap-Alb [The Story of Harap-Alb], which provide the text with charm, liveliness, local colour and, evidently, Romanian rural "authenticity", as it was remarked (GC-O, p. XIV). The dialogue between Poseidon and Hephæstus, regarding the release of Ares ${ }^{24}$, sounds thus:

- Dă-i drumul! Că mă fac chezașul, frate, [Let him go! For I pledge myself, brother,] Că totu-ți va plăti, cît ceri și cît [That he will pay you all that is due to you and what] E datina-ntre zei și-i cu dreptate! [The custom is for gods and it is fair!]

- Ab! De-asta nici nu-ți mai răci cuvîntul. [For that don't even let your word go cold.] (GC-O, VIII, 355-358)

\footnotetext{
${ }^{23}$ The rich inventory selected by Ștefan Cazimir, in his Prefaţă [Preface] to GC-O, it is connected to the influence I. Caragiani might have had on the Romanian poet (p. VII-VIII).

${ }^{24}$ It is known that the Greeks projected onto the gods not only the loftiest human aspirations, but also their common frailties. The resplendent Aphrodite, married by her father to the talented but misshapen Hephæstus, gives in to the advances of handsome Ares, often receiving him in her very conjugal bed. The Sun-The All-Seer-tells the cuckolded husband, who sets them a trap of invisible chains. Ashamed and aggrieved, Hephæstus, however, calls the gods to see the two adulterers in that state. Evidently, he no longer chooses his words, to the amusement of those present. Despite his dishonourable posture, Ares utters a short speech quite befitting the code of honour, and Poseidon, as the highest among those present, proposes a resolution of the crisis, resorting to the principle of payment of damages for moral offence, for which he offers to guarantee himself, cf. Od., VIII, 266-366. The verses quoted above, in the version GC, render only the popular sagacious exchange towards the end of the episode, without the verbal outburst, expressed by "cuvintele mîniei" [the words of anger].
} 
Athena supports Telemachus, but she does not guarantee his final victory, so, in case he should find out that Odysseus/Ulysses is dead, she advises him:

...găsește-i mă-tei omul și-o mărită! [...find your mother a man and give her away!] (GC-O, I, 50)

Of course, such roughness of expression was appropriated by Coşbuc not so much from the German version of the Homeric text, but from the Romanian model offered by Caragiani's translation. The editors remarked such filiations (GC-O, I, p. XVII), and the observations arising from this comparative examination of the texts point to an increased boldness of expression at Coşbuc, borrowed from rural quotidian life. The quarrel between the old beggar Arnaios/Iros, a regular presence at the doors of the palace in Ithaca, and Odysseus, disguised as the foreign beggar who had just arrived from nowhere and had dared join him on the threshold, thus occupying the space where the "native" had been tolerated by the suitors, sounds very much like the quarrel between Creangăs characters-in Harap-Alb, or even in the Mogorogea episode of Amintiri din copilărie [Memories of Childhood]:

"- Aoleo cum hodorogește spurcatul acesta, ca o babă pe cuptor! [Oh my, how that foul-smelling one's snorting, like a hag on the oven]" (IC-O, p. 214)

"-N-auzi, olio, spurcatul de golan [Don't your hear the foul punk]

Cum duruie ca la cuptor o babă! [Wheezing as at the oven a hag does!]” (GC-O, XVIII, 6, 2-3)

At EL, the dialogues sound quite the same. From the exchange Athena-Nestor-Telemachus, which we have partially analysed, we can extract sentences such as these:

Nestor...:

- „Ferească Dumnezeu să mergeți la corabia voastră, ca și cum ațifi tras la un om sărac, ce n'ar avea la casa lui nici așternut, nici scoarțe pe care să se odihnească oaspeții...”

[God forbid you should go to your ship, as if you stopped at a poor man, who would have no bedding in his house, nor any rugs for guests to lie rest on...]

Minerva...:

- „Că bine zici, moşule dragă, și se cuvine ca Telemac să te asculte, că aşa e cu cale...”

['Cause justly you speak, dear old man, and it's proper that Telemachus obey you, as it is right...] (EL-O, p. 36).

By means of such turns of phrase, the entire life tableaux of the Homeric poem are imperceptibly changed so that they can be integrated in to the traditional ambience of the Romanian village. What is achieved, starting from the details of material and social-economic life, etc., and by playing on the pragmatic-stylistic virtues of the Romanian language, is a new suggestiveness of modes of thinking and feeling. Without any knowledge of E. Lovinescu's theories about the mutation of æsthetic values, G. Coşbuc intuitively created, by the sheer force of his poetic genius, new nuances in expressing generally human mentalities, and, moreover, nuances that refashion and naturalize the entire atmosphere, reviving a long bygone world and making it easy to understood for the modern reader of a new cultural climate, spiritually and materially determined by the conditions of contemporary life. The maximum degree of autochthonization means, therefore, that the characters speak, think and act in the national spirit of the version realized in a new culture. Athena tells Nausicaa that "soacra mare așteaptă dar" [the great mother-in-law awaits a gift]; Menelaos will not have such a thing as "să-i plece un oaspete așa, flämînd din casă" [a guest leave his house famished like that]; Evrimah is afraid of becoming "de rîsul lumii-ntre femei" [the laughing stock among women]; Telemachus would not want to be considered "slab de minte" [dim-witted]; Penelope thinks that Elena's haziness is understandable, "căci slabe-s, Doamne, mințile femeii!" [as, God, weak are the minds of women] and so on. 
b) Terminology from diverse domains has constituted a permanent challenge for the translators' competences, both in terms of decoding the significations in the source language, and of finding a balance in the target language.

In the analysis of the nature scene in $O d ., \mathrm{V}, 63-74$-the scenery surrounding the cave of the nymph Calypso-we have identified at least six (!) semantic fields in only eleven verses. The greatest challenges are posed, first of all, by names of trees, plants and birds. Added to these are two names of biotopes - codrul [the woods] and cringul [the grove], as well as the aquatic medium (sea and lake, natural and artificial, alternatively), hard to identify exactly, as both the terms and their description are interpretable. We have shown, where appropriate, how, in any particular language, there can be confusions generated at a diatopic, diachronic and diastratic level, confusions that are accentuated from the contrastive-typological perspective of languages (cf. Bârlea, 2015c). The synonymic and quasi-synonymic series are quite unclearly defined in the framework of a larger semantic field: cucuvea [owl], bufniţă, bubă [eagle owl]; toporaşi [violets], viorele, violete [sweet violets]; ulmi [elms], arini [alders], anini [common alders]; pädure [forest], codru [woods], crîng [grove]; luminiş [clearing], pajişte [meadow], măgură [green hillock]; izvor [source], fîntînă [well], cişmea [fountain]; malul mării [seashore], etc.

In the case of these series, it is easier to choose the old popular form because there is no single literary variant unanimously accepted between the popular, colloquial term and the scientific one (possibly Latin), neither in Romanian nor in other modern languages.

But the specialized lexis of various registers comprises hundreds of terms for representative areas of the Homeric epos. Names of weapons, in the Iliad and the Odyssey, have constituted difficult tests for the linguistic expertise of translators, see above, 2.2.b). When the term is relatively old and in use in both languages, things seem more simple: arc [bow], săgeată [arrow], lance, suliță [spear], sabie [sword], scut [shield], etc. In fact, even in the situation-an ideal, but less frequent one than we would like to believe $\mathrm{e}^{25}$ - of a complete similarity of concept the two languages, translation is complicated by the integration of the term in the specific phrases: in Romanian, the warrior "se încinge cu sabia" [buckles his sword] round his waist, while in Homeric Greek "își atîrna sabia la spate" [he hung his sword on his shoulder] (with a beautifully wrought leather belt), cf. DS-I, p. 401, where there is also the example of about the horse-who were "înjugau" [yoked] to the cart (just like mules, oxen, etc.), because ancient Greeks did not use resistant leather reins.

The choice of a certain form is often determined by the metrical requirements of the verse and not by semantic accuracy: sabie [sword] has three syllables, with a dactylic value, while paloş or spadă have only two, appropriate for a verse ending or for an interior trochaic sequence.

Among these selection criteria, there is the perfidiously nagging demon of the popular customization of the term: custură for "cuțit" [knife], pală for "sabie" [sword], pieptar for "platoșă” [breastplate], culă for "turn întărit" [fortified tower], liman for "țărmul de refugiu" [shore haven], ostrov for "insulă" [island], etc. Sometimes, autochthonization at any price, also reinforced by a sui-generis æstheticism, leads to flagrant mistakes of rendering. Between suliță [spear] and lance, the choice may take into account the syllabic structure or/and the semantic nuance which each of the two terms might be able to express. At GM, however, we find a third term: strămurare. Difficult to fit into the verse types suitable to epical rhythm, due to its phonological-morphological structure, as well as due to its semantic charge, since it represents an archaic term at the margin of the conventional circles configuring the mass of the vocabulary, more precisely in the extreme area of "out of use" words, the item is also, as already shown, inadequately used in context. "Strămurarea" was the sharp-tipped rod or pole used for driving herds of cattle in Romanian villages of old (cf. DLR, s.v.). Even in the very rare situation of its being studded, there are no attestations

\footnotetext{
${ }^{25}$ It suffices to remark that weapons with a long blade, generically called sabie [sword], are very different in terms of manufacturing technique and utilization in different periods and spaces of world civilization, hence the series paloş [cutting blade], iatagan [yataghan], floretă [fending sword], spadă [rapier], and others. From this perspective, we can never know if paloş, pală, sabie represent close synonyms or only quasi-synonyms, respectively names for related, though not identical notions.
} 
of its use as a weapon ${ }^{26}$, and this is logically hard to believe, even in the case of peasants rising to arms with whatever tools they found handy: axes, forks, scythes or clubs.

In connection with the latter "weapons", we should specify that the primitivism of some of them justifies the theory of the shared ancestral stock existing in long-standing Balkan civilizations-Hellenic and Romanian in this case. Reteveiul [the cudgel], ghioaga [the mall], măciuca [the bludgeon] belonged to the arsenal of the Achæans and Trojans, as well as to that of the Romanians, so the linguistic equivalences in the respective texts came about somewhat more simply and naturally. On other occasions, such opportunities escape the notice of readers and even translators, as the term seems too commonly used. In our analysis of the scene of the death of Diores (Il., IV, 517-526), we observed (Bârlea, 2015c, Sec. 3.1) that the Homeric selection $\lambda \tilde{\alpha} \alpha \varsigma$ from the synonymic series $\pi \varepsilon \dot{\tau} \tau \alpha$ etc., was not incidental. The rock that crushed the ankle and tendons of the Epeian hero had a certain configuration: small enough to be held in the hand and thrown at a distance, big and pointed enough to cause disasters. In Romanian, the term pietroi [boulder] fits the context well enough, but the Romanian translators add to it the Homeric epithets: sgrebulos, zgrebințos [rugged, jagged], ascuțit, colțuros [sharp, pointed]. These semantic completions clarify its use, especially the qualifying epithet, which actually expresses through one single word the preamble to the concentrated litany (in a lapidary style, if we are also to make an etymological pun!), at the death of the one struck: nemilostivul pietroi [the merciless rock].

Other lexical areas that grant stature to the Homeric poems, such as the terminology referring to the performance of sacrificial rites, gastronomic terminology, that of containers, etc., cause the same kind of problems, with the same diversified solutions - translation, calque, periphrasis - and with the same centrifugal tendencies of local naturalisation: limbifripte [fried tongues], merinde [victuals], ceaun [cauldron], etc. Manner specifications occur in the linguistic sequences depicting the related actions: the cauldron "is raised" [se ridică]; the victuals are "gobbled" [se îmbucă], etc. Sometimes, word for word translationsverbum a verbo-obscure the meaning of the text: frigări in cinci crăci [meats in five spits] (CA-I, p. LXIII, n. 2). As it was to be expected, the first versions in particular also resort to loans. In 1837, Costache Aristia feels it necessary to justify the Romanian literary term of Latin origin grații [graces] by the fact that he could not find the equivalent of Gr. harites in the Romanian popular stock.

More important are the situations in which he borrowed directly from the original text. In the verse of the rhapsody I, 14, La navele ale repezi Aheilor veni [To the rapid vessels of the Achæans came], the translator added a final chapter note, in which he explains why he preferred to naturalize in Romanian

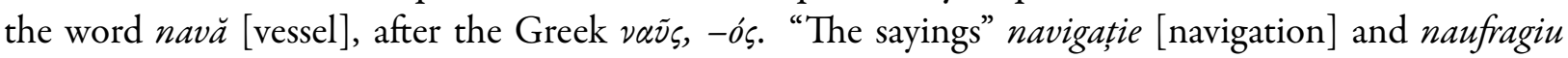
[shipwreck] had been received in our language earlier, confirms the author of the note (probably via a foreign intermediary - French, Italian, etc.), but the word root from which these had been derived in the source languages had not. In order to rid the poem or at least his verses of the saying corabie [ship] "twice as long and ten times more foolish", he thought he could use navă [vessel], so that navigație could become analysable in Romanian. When someone has to break fresh ground, adds the revolutionary philologist, they had better not let the genealogy of these sayings without [an explanation] (CA-I, p. 32, n. 4$)^{27}$.

Thus, autochthonization meant, at the first, resorting to terms in the traditional popular stock of the language of modern versions, referring to objects, beings, processes, phenomena considered rural and archaic even in the structure of the Homeric world. Then the system of beliefs, custom, rituals was adapted to the national specificity, by integrating the pagan divinities into the Christian ethos, into the very national version of the "ancestral faith", id est: Christianity grafted onto pre-Christian remnants, in a syncretism with touches of originality unanimously accepted up to this day. The phenomenon was

\footnotetext{
${ }^{26}$ Nor did this detail escape the notice of the acerbic critic V. Eftimiu, as adept a knower of the Romanian language, from the Pindaric region to the Western Carpathians, and at least as good a poet (Eftimiu, 1996, p. 250-251).

${ }^{27}$ The experts - both classicist philologists and specialists in the history of the Romanian language and in terminologyconfirm C. Aristia's paternity regarding the Romanian form of this word, cf. Rusu (1965, p. 797-800), and also Herescu (2011, p. 387). DLR, s.v., mentions C. Aristia among the first users of the word in Romanian, but considers that its appearance should be explained by multiple etymology (French, Latin, Italian).
} 
favoured by the long-standing tradition of Latinizing the Hellenic Pantheon in Western cultures. Finally, the process was ended cyclically, by amplifying and deepening the lexical aspect at the general level of mentalities, on the one hand, and of social and material realities, on the other. The phrases, expressions, metaphors, morphological-syntactic structures and even ampler constructions that concretize the speech acts, render less of the Homeric specificity and more of the national one, expressed by the internal genius of the receiving language. In this way, the perception of the world through language is drastically changed, and what remains of the texture of the Homeric poem is the epical thread, with the compositional details, etc. The same approach functioned in the other cultures of South-East Europe, in the Serbian, Croatian, Bulgarian, Turkish, Ukrainian versions, etc. The phenomenon was said to have been determined by the common ancestral Indo-European stock, in its Balkanic variant. In fact, it is also found in the translations in the languages and cultured of Iberian peoples and especially Nordic peoples. The rich Scandinavian mythology generated a vocabulary and onomastics easily adaptable to the background of Greek Antiquity.

\section{Conclusions}

3.1. From the point of view of the evolution of the literary language that "clothed" the Romanian versions of the Homeric poems, we can very clearly distinguish three great phases in the history of these translations, even if there were not a few successive resumptions. In the $19^{\text {th }}$ century, C. D. Aristia and I. Caragiani, the founders of the tradition of the translation from Homer, made great efforts to detach themselves from the sphere of colloquial language, by introducing some neologisms (navă [vessel], etc.), as a result of linguistic calque, of direct loans, as well as of internal creations, based on the rich derivative system existent in the national language, by means of bold compounding and conversions. The basis of the "new literary language" remains, however, the popular stock, programmatically utilized in IC, from two familiar reasons: a) high Romanian literature and culture in general were still insufficiently developed so as to furnish the linguistic material from a supra-dialectal sphere, normed and codified according to functional styles; b) the translators of the time shared the conviction that the Homeric world was one predominantly rural and primitive in many respects. After half a century, things changed significantly. The interwar Romanian Homerologists (G. Murnu, G. Coşbuc, C. Papacostea, E. Lovinescu) benefited from a standard literary language already well settled in a coherent normative system, with rich poetic variants, sustained by a national literature visibly connected to the European rhythms. Since then, the choice for popular forms was justified more by the translators' ideology, by their desire to refashion the poetic language, through elements that fitted, however, into the rigours of the elevated style. It was the age of the most daring individual creations, partially dictated by the need for rendering some words and phrases from the highly particular language of the original, the so- called "Homeric Greek". The third and most recent phase of the Romanian translations from Homer (the end of the $20^{\text {th }}$ century and the beginning of the $21^{\text {st }}$ ) is characterized by the cultivation of the savant style, in which even the numerous popular forms acquire the sparkling of gems finely set in the lexical mosaic of the a poetic language meticulously distilled from all the levels and registers of the Romanian language. The crucial principle in the thinking of HâncuDiamandescu, and especially of D. Sluşanschi is fidelity - in content and form-towards the original text and, at the same time, towards the nature of their language. It is certain that the struggle of almost two centuries for naturalising the Homeric poems in the Romanian culture contributed to the refinement of the national literary language.

3.2. The final result of the all the kinds of approaches to translation discussed above should lead to a form supposed to blend contraries in literary work: fluidity and denseness, clarity and implicit suggestiveness, concision and musicality. For all these, as it is often claimed, the translator himself should have poetic gift. On the other hand, the same toiler should be a true scholar, a specialist in the problems of the civilization of ancient Greece, from all points of view-in-depth linguistic and cultural knowledge, permanently connected to the advancements of studies in the field. Thirdly, there is the requirement of the relative objective 
factor, maybe the most important for a good translation: the receiving language should be mature enough with regard to its history, rich and mellifluous enough in its nature so as to enable the poetic genius and specialist knowledge to find its space of manifestation in a double, oxymoronic hypostasis: loyalty and creativity towards both texts- the original one and its own version.

3.3. We have verified these truths primarily by means of an applied analysis of the phonological-morphological level of utilization of the lexical material in the Romanian versions of the Homeric poems. When various distortions, truncations, unusual word associations, especially in conjunct forms, appear in the prose versions-the texts realized by I. Caragiani, E. Lovinescu, Hâncu-Diamandescu-such deviations from the norm can represent phenomena of expressive grammar: intr-ascuns, $n$-a ajuns, nevastă-sa, și-l așeză, etc. Verse translations considerably increase the manifestations of this phenomenon, due to metrical necessities. In the above pages we have captured, as much as possible, only a few examples of such situations. The various concretizations of elisions, syncope, apheresis, with variants of realization in synesis and ellipse, can be mandatory, dictated by the encounter between two or even three etymological units, or by the use of conjoined articulation in slow tempo, which follow the natural law of minimal effort in uttering words: parcă for pare că [it seems that]; tat-tău for tatăl tău [your father]; ş-om vedea for şi vom vedea [and we shall see]. We did not dwell upon the coherent rendering of the usual phrases of this type, born out of the euphonic necessities to be expected in everyday speech. We have highlighted instead the programmatically exaggerated search for certain fusions, abbreviations, dislocations of stress that go beyond the rules known to and accepted by speakers, the segmental reorganizations at the border between colloquial and connotative, for the sake of some innovatory effects. Evidently, such investigations can only be undertaken separately in the successive Romanian versions, on the one hand, in relation to the Greek versions serving as source texts, on the other hand, since the different phonetic and morphological-lexical nature of the languages in the two sets of texts does not allow for rigorous correspondences even for the most learned and talented translator ${ }^{28}$. For example, the original incipit of the Iliad contains no form

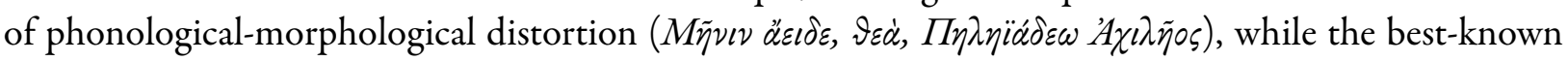
Romanian version presents two such adaptations (...minia ce-aprinse pe-Abil Peleianul); conversely, Gr.

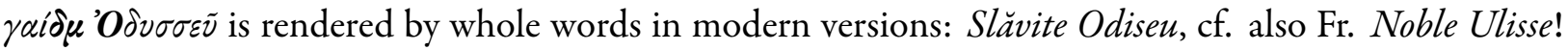
Consequently, we should observe that such phenomena depend less on the diachronic evolution of the literary, poetic language, but rather more on the translator's balanced vision. Apart from the imitative harmonies expressly required by the original text, such as euphonies and alliterations, such phonologicalmorphological particularities should be resumed in a systematic analysis of the expressive values of the texts under discussion, as those which seem usual natural phenomena also confer, in fact, "a sort of melodiousness added to the utterance of the words" (Demetrios, 1943, 70). From the perspective of some modern translation theorists, rhythm is decisive in any kind of text rendered in a foreign language. If a true translation means sensing and rendering the rhythm and internal melodiousness of the text (Dessons \& Meschonnic, 1998, p. 28: «le rythme... l'organisation du mouvement de la parole par un sujet»), then the value of the versions realized after the Homeric poems-prevalently intoned in their genuine form - can only be evaluated by means of a close analysis of such detail effects of the forms rendering the utterance of words.

3.4. One way or another, irrespective of the express formulation of their option, all the Romanian translators exploited the principle of autochthonization. D. Slușanschi, himself a professed opponent of onomastic Latinising and Romanian naturalising, of the deviation of the Hellenic Pantheon from its meaning, resorts to the solution of popular native forms, in critical situations regarding the form, the semantic valence and

\footnotetext{
${ }^{28}$ Not even the adaptation of the poems from Homeric Greek can allow a full equivalence of such particularities. The version realized by Nikos Kazantsakis in katharevousa, the literary variant of Modern Greek, seems richer in such reorganizations of the norms of co-articulation than the ancient text, popular in style, therefore freer of any kind of phonological-morphological constraints.
} 
the place of a word or phrase in the Romanian hexameter. Beyond the precision of the equivalence, scientifically provable, there is the satisfaction of having found the inspired appropriate word, full of suggestion, finely polished to attain a certain sparkle amidst the masterfully laced chain of the beautifully and solidly crafted verse. What's more, not even he can resist the temptation, and neither could C. Papacostea in his day, of offering the Homeric nymphs the face of Zinei Zinelor [the Fairy of Fairies] (CP), and even "sălașul... Cosinnzenei" [the abode of Cosânzeana] (DS) from the realm of our pastoral legends. And it could not have been any other way, at least of the level of everyday lexis, for at least three reasons, easy to understand by anyone:

a) The Homeric text remains, as we have said before, a model of archaic oral quality, of traditionalism, simplicity, naivety, even a primitivism of human reactions at times, elevated to the stature of universality by means of a work of artistic perfection. The sensibilities, vanities, fears, attitudes of the Homeric world are ingenuous and deeply human, at the same time, and the words used to express them do not unduly complicate this reality. In Homeric Greek, a newly-born Achæan or Trojan is said to "vede soarele / lumina zilei" [see the sun / the light of day] (Il., IV, 1112) ${ }^{29}$, as it is in the living, popular Romanian language, as well as in the language of any human community on earth.

b) The Romanian literary language was closely linked to its popular variants, from its beginnings to the present day, whatever specialists might say. A story woven in an idiom pre-eminently poetic-distilled from all the sources of the language spoken throughout the stages of its epic genesis-could only be refashioned in modern languages by replications following the same structure.

c) In any translation in the world, there are frequent situations in which "the right word", meant to compensate for forms, meanings and grammatical-pragmatic constructions in the source language, can only be found in the reserves of the national popular stock. There are few abdications from a correct and suggestive rendering in favour of a formal, elevated, but more arid variant of the literary language, often unexciting and unsuited to the spirit of the primary text. These are but manifestations of a discreet autochthonization, sometimes involuntary or unconscious perhaps, but always unavoidable and fulfilling.

3.5. The Romanian versions of the Homeric poems confirm a paradox of translations, remarked long ago in linguistic circles with a vast experience in the domain: the great literary masterpieces of mankind do not disarm the translator determined to carry it through, quite the contrary, they rather fortify one and stimulate one's creative resources, nourished by the spirituality of one's own people. In the terms of the modern science of traductology, this means that, in relation to the Iliad and the Odyssey, it is unthinkable to speak of the "translator's invisibility", as some recent theories would suggest (cf. Venutti, 1995, p. 306). Paying due respect to the otherness of the original text and to the stranger it represents (Berman, 1991), the Romanian versions allow what the present generation of translation theorists call "the identification of the translator's voice" (Hermans, 1996). More timid at the first translators in the Romanian history of Homeric versions (CA and IC), and well held in check at the more recent ones (HD and especially DS), this "secondary voice", accompanying throughout the discourse in the original text ${ }^{30}$, makes itself felt more poignantly in the translations of GC and GM, of different values, of course, but equally appropriated.

3.6. Regarding the manifestations of the relation between language and thought in the process of translation from the Homeric texts, we have to say that the adaptations to the specificity of the receiving language, however massive, are never so overwhelming as to deviate in any way the essence of the Greek original. The two Homeric epics are much too powerful constructions, too solidly wrought and endowed with a timeless force radiating through millennia of posterity, to be susceptible of being overshadowed by the national garb of the translations, however programmatically naturalised.

\footnotetext{
${ }^{29} \mathrm{Cf}$. also Il., IV, 724, the verse in which Menelaos identifies life with sunlight.

${ }^{30}$ The researchers in the school represented by Helmans even realised diagrams registering the presence of this voice of the "double of the author" of the original, cf. Schiavi (1996).
} 
3.7. What these poems offer is not only the matrix of a culture and civilization that constitute the bedrock of the modern world, but also the model for forging some national languages of a high philosophical and artistic stature. The above-mentioned current tenet regarding the status of an already recognised poet required of a good translator from Homer (those unanimously recognised in our culture being GC and GM) is also reversed in the history of the reception of these translations: some scholars became poets after working on the Homeric texts. Simplicity and purity, profoundness and ethereal heights, localism and universality - these are only a few of the elements configuring the national literary language of the translators, refined in the complicated distilling operation of the Homeric poems.

\section{Bibliography}

A. Sources

\section{A.1. Text editions}

Il-A-H-C = Homers, Ilias, edited by Ameis, K.F., Hentze, C. \& Camer, P., 2 vol. ( $\times 4$ facs), ed. 4-8, Leipzig: Teubner, 19051932. Reimpr.: Hidesheim, 1970.

Il-M-A = Homer, Iliad, edited by Monro, D. B. \& Alen, Th. W., Vol. I-II, Oxford: Clarendon Press 1924/1966²

Il-PM = Homère, Iliade, edited by P. Mazon et al., Tomes I-IV, Paris: Les Belles Lettres, 1974.

Il-Pope $=$ The Iliad of Homer, translated by Al. Pope, with notes by the Rev. Th. A. Buckley, M.A., F.S.A. and Flaxman's Designs, London, 1899 [online].

Od-Murray $=$ Homer, The Odyssey with an English Translation by A.T. Murray, PhD in two volumes, Cambridge, MA: Harvard University Press; London: William Heinemann, Ltd., 1919.

PP-I = Iliad online version from the Perseus Project (PP) translation and hyperlinks (Homeri Opera in five volumes, edited by Monro, D. B. \& Alen, Th. W., Oxford: University Press, 1920.)

$\mathrm{pP}-\mathrm{O}=$ Odyssey online version from the Perseus Project (pP) translation and hyperlinks (Homer, The Odyssey with an English Translation by A.T. Murray, PhD in two volumes. Cambridge, MA: Harvard University Press; London: William Heinemann, Ltd. 1919.).

\section{A.2. Translations into Romanian}

\section{A.2.1. Iliada / The Iliad}

CA-I = Omer, Iliada, Tome I. Cantos I-VI. Translation by C. Aristia, Bucureşti: Tipografia lui Eliad, 1837 (blank verse).

DS-I = Homer, Iliada . Translated in hexametres, with a postface, bibliography and indices by D. Sluşanschi and illustrated by

M. Coşulețu, Bucureşti: Editura Humanitas, 2012.

GM-I = Homer, Iiada. Translated in Romanian by G. Murnu. Recipient of The Great Award of the Romanian Academy,

[Bucureşti]: Cultura Națională, [1920].

GMD-I = Homer, Iliada. Translation in the original metre by G. Murnu. Introductory study and notes by D.M. Pippidi.

Definitive edition. Bucureşti: Editura pentru Literatură Universală, 1967.

$\mathrm{GMF}_{1}-\mathrm{I}=$ Homer, Iliada. Translation in the original metre by G. Murnu. Supervision, introductory study, notes and glossary

by L. Franga, Bucureşti: Editura Univers, 1985.

$\mathrm{GMF}_{2}-\mathrm{I}=$ Homer, Iliada. Translation in the original metre by G. Murnu. $2^{\text {nd }}$ edition, with a new introductory study, notes, preface to the edition and glossary by L. Franga, Bucureşti: Editura Fundaţiei Culturale, 1995.

HD-I = Homer, Iliada. Translation [in prose] by R. Hâncu and S. Diamantescu. Vol. I-II, Bucureşti: Editura Minerva, 1981. RH-I = Homer, Iliada . Translation by R. Hâncu. Foreword by G. Hâncu. Bucureşti: Editura Mondoro/Editura Gramar, 2011.

\section{A.2.2. Odiseea / The Odyssey}

$\mathrm{CP}-\mathrm{O}=$ Homer, Odysseia, I-XII. Translation by C. Papacostea, 1929. Introduction, note on the edition, notes and indices by

I. Costa, Bucureşti: Editura Muzeului Literaturii Române, 2013.

DS-O = Homer, Odysseia. Translation in hexametres by D. Sluşanschi. Bucureşti: Editura Paideia, 2009.

DS-Or = Homer, Odysseia. Translation in hexametres, with postface, bibliography and indices by D. Sluşanschi and illustrated by D. Rădvan. Revisions and completions by O. Gordon and F. Băltăceanu. Bucureşti: Editura Humanitas, 2012.

$\mathrm{EL}-\mathrm{O}=\mathrm{Homer}$, Odiseea . Translation in prose by E. Lovinescu. Foreword and notes by E. Mazilu-Lovinescu, Bucureşti: Editura MondoRo, 1995.

EL-Or1 = Homer, Odiseea. [Translation by E. Lovinescu. Text revised and annotated by T. Costa. Introductory study and indices by M. Nasta], Bucureşti: Editura pentru Literatură, 1963. ( $1^{\text {st }}$ ed.: 1935)

"The bibliographic references have in view the integral form of this study, which continues the part published in issue 2/2015 of "Diacronia". 
EL-Or2 = Homer, Odiseea, Vol. I-II. Translation by E. Lovinescu. Text revision and notes by T. Costa. Preface by V. Antonescu, Bucureşti: Editura Tineretului, [1966].

EL-Or3 = Homer, Odiseea. Translation by E. Lovinescu. Edition revised and postface by T. Diaconescu. Bucureşti: Saeculum I. O., 1996.

$\mathrm{EL}-\mathrm{Or}_{5}=$ Homer, Odiseea $\left(5^{\text {th }}\right.$ edition). Translation by E. Lovinescu. Introductory study and indices by Mihai Nasta. Text revision and notes by Traian Costa, Editura pentru Literatură, București, 1963.

GC-O = Homer, Odiseea, vol. I-II. Translation by G. Coşbuc. Edition supervised by I. Sfetea and Şt. Cazimir. Preface by Şt. Cazimir. Bucureşti: Editura pentru Literatură, 1966. (Mss. 1916).

$\mathrm{GM}-\mathrm{O}=$ Homer, Odissea. Translation by G. Murnu. Introductory study and notes by A. Pârvulescu. Bucureşti: Editura Univers, 1979.

GM-Od = Homer, Odiseea. Translation by G. Murnu. Introductory study and notes by D.M. Pippidi. Definitive edition, Bucureşti: Editura Univers, 1971. (1 ${ }^{\text {st }}$ ed.: 1928)

IC-O = Odiseea. Batrachomyomachia - Războiul şoarecilor cu broaştele. Translation in prose, notes and prezentations by $\mathrm{I}$. Caragiani. Argument. Notes on the edition by I. Acsan, Bucureşti: Editura MondoRo, 2011. (1 $1^{\text {st }}$ ed. - Iași: H. Goldner, 1876)

\section{B. References}

Acsan, I. (1984). Constelația corifeilor... [The Constellation of the Coryfæi...], Editura Cartea Românească, București.

Ameis, K. F. \& Hentze, C. (1965a). Anhang zu Homers Ilias, ediția a IV-a, vol. I-II, De Gruyter, Amsterdam.

Ameis, K.F. \& Hentze, C. (1965b). Anhang zu Homers Odysee, ediția a IV-a, vol. I-II, De Gruyter, Amsterdam.

Aristotel (1965). Poetica, translation by D. M. Pippidi, Editura Academiei, București.

Bailly, C.A. (1950). Dictionnaire grec-français, Hachette, Paris.

Barbu, N.I.; \& Piatkowski, A. (1978). Scriitori greci şi latini [Greek and Latin Writers], Editura Științifică și Enciclopedică, București.

Bârlea, P.Gh. (2008). Limba poveștilor populare românești [The Language of Romanian Fairytales], Editura Academiei Române, București.

Bârlea, P. Gh. (2014). Româna literară în fața poemelor homerice [Literary Romania Face to Face with the Homeric Poems], in: Bârlea, P. Gh. \& Toma, F. R. (coord.), Cultură și comunicare, Editura Muzeul Literaturii Române, București, p. $27-31$.

Bârlea, P.Gh. (2015a). Autohtonizarea textelor homerice în versiunile sud-est europene, in: Spăriosu, L. \& Popovici, V. (coord.), Communication, Culture, Creation: New Scientific Paradigms, Europa Press, Novi Sad - Arad, p. 23-37.

Bârlea, P.Gh. (2015b). Ipostaze ale homerismului în literatura universală [Hypostases of the Homeric Problem in World Literature], in "Litere", XVI, 3, (180), p. 67-69.

Bârlea, P.Gh. (2015c). The Homeric poems in Romanian attire. A diachronic analysis (I), in "Diacronia”, 2, July 17, art. A18, CrossRef.

Berman, A. (1991). La traduction et la lettre ou l'auberge du lointain, Seuil, Paris.

Camps, W.A. (1980). An Introduction to Homer, Oxford University Press, Oxford.

Chantraine, P. (2009). Dictionnaire étymologique de la langue grecque. Histoire des mots, vol. I-II, Klincksieck, Paris.

Demetrios of Phalerum (1943). Tratatul despre stil [Treatise on Style], translation, introduction, and commentary by C. Balmuș, Tipografia Alexandru A. T,erek, Iași.

Dessons, G. \& Meschonnic, H. (1998). Traité du rythme. Des vers et des proses, Dunod, Paris.

DLR = Dicționarul limbii române, ediție anastatică după Dicționarul limbii române (DA) și Dicționarul limbii române (DLR), tomul XV, Editura Academiei, București.

Eftimiu, V. (1996). Opere, vol. 18, Memorialistică. Publicistică literară, ediție și note de Constantin Mohanu, Editura Minerva, București.

Eminescu, M. (1952). Opere [Works], vol. IV, Poezii postume. Anexe. Introducere. Tabloul edițillor [Posthumous Poems. Annexes. Introduction. Overview of editions], critical edition cared by Perpesiccius, Editura Academiei R.P.R, București.

Eminescu, M. (1958). Opere [Works], vol. V, Poezii postume. Anexe. Note și variante. Exerciții și moloz. Addenda și corrigenda. Apocrife. Mărturii [Posthumous Poems. Annexes. Notes and variants. Exercises and debris. Addenda and corrigenda. Apocryphal pieces. Confessions], indices, critical edition cared by Perpessicius, Editura Academiei R.P.R., Muzeul Literaturii Române, București.

Foucault, M. (1998). Ordinea discursului. Un discurs despre discurs [The Order of Discourse. A Discourse on Discourse], translation by Ciprian Tudor, Eurosong \& Book, București.

Georgescu, N. (2005). Homer - contemporanul nostru [Homer - Our Contemporary], in: Recife. Eseuri de oceanografie, Editura „Floare Albastră”, București, p. 11-51.

Herescu, N.I. (1929). Homer: Iliada. In românește de George Murnu (Cultura națională), in: "Revista Clasică. Orpheus. Favonius", V, I, 1-4, p. 68-70.

Herescu, N.I. (2011). Destin fără moarte (Pentru clasicism) [Immortal Destiny (For Classicism)], edition, note on the collection, note on the edition, introductory study by Liviu Franga, Editura Muzeul Literaturii Române, București.

Hermans, T. (1996). The Translator's Voice in Translated Narrative, in "Target", vol. 8/1, p. 23-48, CrossRef. 
Kirk, G. (coord.) (1985-1993). The Iliad: A Commentary, vol. I-VI, Cambridge University Press, Cambridge, CrossRef. Lascu, N. (1974). Clasicii anticii în România [The Ancient Classics in Romania], Editura Dacia, Cluj-Napoca.

Lord, A. (1960). The Singer of Tales, Harvard University Press, Cambridge, MA.

Lovinescu, E. (2012). O privire asupra clasicismului [A Perspective on Classicism], edition supervised, introductory study, note on the edition, notes and commentaries by P. Gh. Bârlea, Editura Muzeul Literaturii Române, București.

Marinescu-Himu, M. \& Piatkowski, A. (1972). Istoria literaturii eline, Editura Științifică, București.

Meister, K. (1966). Die homerische Kunstsprache, ediția a II-a, Teubner Verlag, Darmstadt - Leipzig, CrossRef.

Parry, M. (1971). The Making of Homeric Verse, in: The Collected Papers of Milman Parry by Adam M. Parry, Oxford University Press, Oxford.

Platon (1983). Opere [Works], vol. IV, edition supervised by Petru Creția, Editura Științifică și Enciclopedică, București.

Risch, E. (1973), Wortbildung der homerischen Sprache, ediția a II-a, De Gruyter \& Co., Berlin - New York, Tome II: Syntaxe (1997), CrossRef.

Rusu, V. (1965). C. Aristia și problemele cultivării limbii la mijlocul secolului al XIX-lea [C. Aristia and the Problems of the Cultivation of Language at the Middle of the $19^{\text {th }}$ Century], in: Omagiu lui Alexandru Rosetti, Editura Academiei, București.

Schiavi, G. (1996). There is Always a Teller in a Tale, in "Target", vol. 8/1, p. 1-21, CrossRef.

Stoica, G. (2012). Afect și afectivitate. Conceptualizare și lexicalizare în româna veche [Affect and affectivity. Conceptualization and lexicalization in Old Romanian], Editura Universităţii din București, București.

Ursu, N.A. (1962). Formarea terminologiei științifice româneşti [The Formation of Romanian Scientific Terminology], Editura Științifică, București.

Wace, A.J.B. \& Stubbings, F.H. (1963). A Companion to Homer, Macmillan \& Co., London - Toronto.

Venutti, L. (1995). The Translator's Invisibility: A History of Translation, Routledge, London / New York.

Whitman, C.H. (1958). Homer and the Homeric Tradition, Harvard University Press, Cambridge, MA. 